University of Maryland Francis King Carey School of Law

DigitalCommons@UM Carey Law

\title{
Technological Triggers to Tort Revolutions: Steam Locomotives, Autonomous Vehicles, and Accident Compensation
}

Donald G. Gifford

University of Maryland School of Law, dgifford@law.umaryland.edu

Follow this and additional works at: https://digitalcommons.law.umaryland.edu/fac_pubs

Part of the Legal History Commons, Science and Technology Law Commons, and the Torts Commons

\section{Digital Commons Citation}

Gifford, Donald G., "Technological Triggers to Tort Revolutions: Steam Locomotives, Autonomous Vehicles, and Accident Compensation" (2017). Faculty Scholarship. 1590.

https://digitalcommons.law.umaryland.edu/fac_pubs/1590

This Article is brought to you for free and open access by the Francis King Carey School of Law Faculty at DigitalCommons@UM Carey Law. It has been accepted for inclusion in Faculty Scholarship by an authorized administrator of DigitalCommons@UM Carey Law. For more information, please contact smccarty@law.umaryland.edu. 


\title{
TEChNOLOGICAL Triggers to TORT Revolutions: Steam Locomotives, Autonomous Vehicles, AND ACCIDENT COMPENSATION
}

\author{
11 J. Tort Law __ (forthcoming 2018)
}

\section{Donald G. Gifford*}

Abstract: Waves of technological change explain the most important transformations of American tort law. In this Article, I begin by examining historical instances of this linkage. Following the Industrial Revolution, for example, machines, no longer humans and animals, powered production. With greater force, locomotives and other machines inflicted far more severe injuries. These dramatic technological changes prompted the replacement of the preexisting strict liability tort standard with the negligence regime. Similarly, later technological changes caused the enactment of workers' compensation statutes, the implementation of automobile no-fault systems in some states and routinized automobile settlement practices in others that resemble a no-fault system, and the adoption of "strict" products liability. From this history, I derive a model explaining how technological innovation alters (1) the frequency of personal injuries, (2) the severity of such injuries, (3) the difficulty of proving claims, and (4) the new technology's social utility. These four factors together determine the choice among three liability standards: strict liability, negligence, and no-fault liability with limited damages. I then apply this model to the looming technological revolution in which autonomous vehicles, robots, and other Artificial Intelligence machines will replace human decision-making as well as human force. I conclude that the liability system governing autonomous vehicles is likely to be one similar to the workers' compensation system in which the victim is relieved of the requirement of proving which party acted tortiously and caused the accident.

\footnotetext{
* Jacob A. France Professor of Torts, University of Maryland Carey School of Law. I am grateful to my colleagues Richard Boldt, Danielle Citron, Frank Pasquale, Sarah Bloom Raskin, Christopher Robinette, and Max Stearns for reviewing earlier versions of this Article and offering valuable suggestions. I also thank my research assistants Mena Gaballah, Peter Honnef, Charles Kassir, Lauren Miller, Joshua Prada, and Carolyn Schorr. Finally, I appreciate the editorial and research help of Maxine Grosshans and Sue McCarty, both from the Thurgood Marshall Law Library.
} 


\section{Table of Contents}

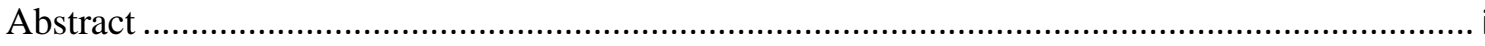

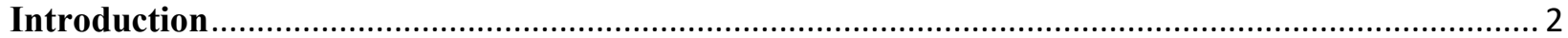

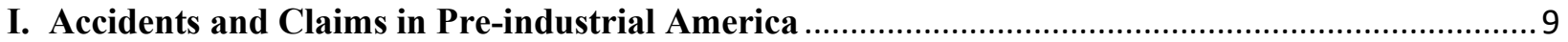

A. Personal Injury Accidents in Pre-Industrial America ......................................................... 9

B. The Paucity of Personal Injury Claims in Pre-Industrial America ..........................................11

C. The Strict Liability Standard in the Law of the Pre-Industrial Era ...........................................14

II. The First American Technological Revolution and the Development of Negligence..................16

A. The Industrial Revolution, Railroads, and the Resulting Human Carnage ...............................17

B. The Burgeoning Frequency of Personal Injury Claims .......................................................20

1. The Emergence of Large Business Enterprises .................................................................. 20

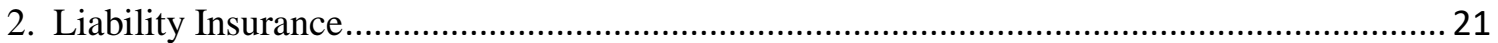

3. The Abolition of the Witness Disqualification Rule ............................................................. 22

4. The Emergence of the First-Generation Specialized Personal Injury Bar............................... 23

C. The Development of the Classical Negligence Regime …....................................................25

1. The Law Governing Liability for Personal Injuries by the late-Nineteenth Century ..............25

2. The Economic Explanation for the "Radical Transformation" of Nineteenth Century Tort

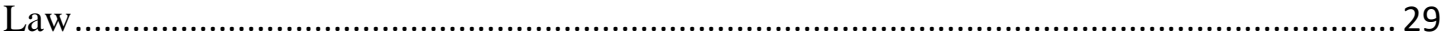

3. Alternative Explanations for Changes in Nineteenth-Century Tort Law ............................... 34

D. Technology as the Cause of the Classical Negligence Regime.................................................37

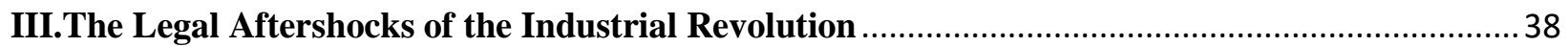

A. The Factory System and the Enactment of Workers' Compensation .........................................39

B. The "Evil Deity's" Gift of the Automobile ................................................................................... 43

C. The Rise and Fall of Strict Products Liability ........................................................................ 49

1. The End of the Privity Requirement.................................................................................... 49

2. The Emergence of "Strict" Products Liability........................................................................ 50

3. The Reversion to Fault-Based Standards in Products Liability ............................................. 52

4. Assessing the Product Liability "Revolution"........................................................................ 55

IV. The Association between Technological Progress and Changes in the Law of Personal Injury Compensation.

V. The Second American Technological Revolution-Autonomous Vehicles, Robots, and Artificial Intelligence—and the Future of Liability Law 


\section{Introduction}

Originalists find themselves strangely out of place when it comes to tort law. The personal injuries that dominate tort law, the smashing of bones by automobiles and other powerful machines and the horrible diseases resulting from exposure to asbestos or lead-based paint, did not exist in the late-eighteenth century. Not coincidentally, today's law governing compensation for personal injuries would be unrecognizable to the Founders. Moreover, technological change has not ended. Instead, American society finds itself on the cusp of a looming technological revolution, the Information Age, that will make autonomous vehicles, robots, and other products incorporating artificial intelligence ubiquitous parts of everyday life.

In this Article, I trace how successive waves of technological change in American society contributed to the development of law governing liability for personal injuries. Each new wave of technology rips the fabric of the preexisting law governing compensation for accidental personal injuries. ${ }^{1}$ From this history, I derive a descriptive model that analyzes how the technological changes resulting from the Industrial Revolution, including the development and proliferation of railroads, led to the installation of the negligence regime during the midnineteenth century.

In the first decades of the twenty-first century, a model that associates technological and legal change is more than a matter of academic curiosity. It assists us in predicting the future of the law governing personal injury claims arising from autonomous vehicles and other devices where the machines themselves perform the decision-making, as well as supplying the force that causes personal injuries.

\footnotetext{
${ }^{1}$ Jack Balkin observes that "[i]nstead of saying that law is responding to essential features of new technology, it might be better to say that social struggles over the use of new technology are being inserted into existing features of law, disrupting expectations about how to categorize situations." Jack M. Balkin, The Path of Robotics Law, 6 CALIF. L. Rev. CirCuIT 45, 50 (2015), http://www.californialawreview.org/wp-content/uploads/2015/06/BalkinCircuit.pdf.
} 
Given that the staggering amounts of personal injuries in modern society that result almost exclusively from machines and toxic substances that did not exist before the Industrial Revolution, it is surprising that no other tort scholar or legal historian has comprehensively tracked how changes in tort law flow from technological change. ${ }^{2}$ Other legal historians and tort scholars, notably Morton Horwitz, Lawrence Friedman, and Gary Schwartz, have previously considered the role of technological change during the nineteenth century, particularly the emergence of railroads, as a possible cause of the development of negligence law. ${ }^{3}$ Even here, however, their scholarly debate of a generation ago focused more on whether the changes in law were intended to shift the distributional consequences of harms caused by new technologies, that is, which socioeconomic class would bear the economic brunt of injuries, rather than on how changes in technology, in and of themselves, precipitated changes in the law. Additionally, these scholars left us without a comprehensive theory explaining the role played by technological advancements in changing tort law. Other factors, including not only politics and ideology, but also race, gender, and socioeconomic considerations, obviously affect the development of tort law. ${ }^{4}$ However, because actionable tortious injuries almost always directly involve products of

\footnotetext{
${ }^{2}$ A rich literature exists tracing the impact of technology on other aspects of tort law, such as invasion of privacy torts. See, e.g., Danielle Keats Citron, Mainstreaming Privacy Torts, 98 CALIF. L. REv. 1805, 1819-21, 1826-28 (2010) (describing the origins of the invasion of privacy torts in the technologies of the late nineteenth-century and advocating updates to the law to reflect modern website and database technology). Moreover, a few scholars have begun to address the specific issues arising from the impact of robotics in causing physical injuries. See, e.g., Balkin, supra note 1, at 45-55 (considering the interaction between robotic technologies and the law); Ryan Calo, Robotics and the Lessons of Cyberlaw, 103 CALIF. L. REV. 513, 515, 534-35 (2015) ("Robotics is shaping up to be the next transformative technology of our time.... A transformative technology such as ... robotics matters insofar as it changes the range of human experiences in ways that undermine the balance the law hopes to strike"); Nora Freeman Engstrom, 3-D Printing and Product Liability: Identifying the Obstacles, 162 U PA. L. REV. ONLINE 35, 36 (2013), http://www.pennlawreview.com/online/162-U-Pa-L-Rev-Online-35.pdf (analyzing the products liability issues arising from 3-D printing and stating that "[f]ollowing any significant technological breakthrough, legal scholars, practitioners, and policymakers must consider how the innovation meshes with —or poses challenges toour existing laws").

${ }^{3}$ See infra notes $148-172$ and accompanying text.

${ }^{4}$ See, e.g., Martha Chamallas \& Jennifer B. Wriggins, The Measure of InJury: Race, Gender, AND Tort LAW (2010); Donald G. Gifford \& Brian Jones, Keeping Cases from Black Juries: An Empirical Analysis of How
} 
technology, the lack of scholarly attention to the history of technology appears initially to be a curious omission.

To understand why legal scholars avoid the history of technology and its impact on the law, let us consider the broader scholarly realm, where the history of technology is similarly decidedly out of vogue. ${ }^{5}$ Technological determinism, once the dominant perspective of the history of technology, rested on the proposition that technological change was the cause of socioeconomic and political transformation. ${ }^{6}$ This perspective often morphed into an elitist celebration of Western civilization and its technological accomplishments. ${ }^{7}$ Leo Marx notes that for many historians of technology, “[t]he West's dominant belief system, in fact, turned on the idea of technical innovation as a primary agent of progress." 8 This optimistic, Western-oriented school of technological determinism, however, became decidedly unpopular during the latetwentieth century. Identifying human progress as technological progress could not survive "Hiroshima, the nuclear arms race, the American war in Vietnam, Chernobyl, Bhopal, the Exxon oil spill, acid rain, global warming, [and] ozone depletion." 9 Additionally, the study of history (and the law) now more fully and accurately reflects the perspectives of those who had not fared

Race, Income Inequality and Regional History Affect Tort Law, 73 WASH. \& LEE L. REV. 557, 617-19 (2016) (confirming, empirically, the effect of race on changes in tort law and evaluating the possible effects of income inequality).

${ }^{5}$ John M. Staudenmaier, Rationality versus Contingency in the History of Technology, in DOES TECHNOLOGY DRIVE History?: The Dilemma of TeChNOlogical Determinism 259, 260-61 (Merritt Roe Smith \& Leo Marx, eds., 1994) [hereinafter "DOES TECHNOLOGY DRIVE HISTORY?"] (observing that "the work of historians of technology is so often ignored in the historical mainstream"; further noting the "total absence of historians of technology" from a debate over the proper subjects of historical interpretation).

${ }^{6}$ Historians variously find the genesis of technological determinism in the work of, among others, Thorstein Veblen, see THORSTEIN VEBLEN, THE THEORY OF Business ENTERPRISE 303 (Charles Scribner's Sons 1932) (1904) (“The factor in the modern situation that is alien to the ancient regime is the machine technology, with its many and wide ramifications.”) and Karl Marx, see KARL MARX, THE POVERTY OF PHILOSOPHY 109 (Int'1 Publishers Co., Inc.6th prtg. 1975) (1847) ("The hand-mill gives you society with the feudal lord; the steam-mill, society with the industrial capitalist.").

${ }^{7}$ See Studenmaier, supra note 5, at 271 (noting that the traditional school of historians of technology "might suggest that the people who identify with Western, quantified, rational, scientific-technological progress reveal ... an [unblushing] elitism" ... They might be saying "Face it: Western science, Western practice, Western economics have in fact swept the opposition from the field, and the only people who really don't get it are those who are illiterate of the language of the past couple of hundred years").

${ }^{8}$ Leo Marx, The Idea of "Technology" and Postmodern Pessimism, in Does TeChNOLOGY DRIVE History?, supra note 5, at 240 (further stating that "between 1750 and $1850 \ldots$ at more popular levels of culture, ... progress ... was exemplified by innovations in the familiar practical arts.").

${ }^{9} \mathrm{Id}$. at 238 . 
as well during the post-Enlightenment technological era, such as those living in both underdeveloped countries and less affluent communities. ${ }^{10}$

Ironically, the flight from the study of technology as a cause of socioeconomic change encompassed even ignoring technology's role in causing unwanted and deleterious consequences. ${ }^{11}$ This scholarly gap is particularly germane to the study of those aspects of tort law governing compensation for personal injuries. Nineteenth-century technological changes increased the severity of tortiously caused personal injuries. The force and momentum of machines, such as locomotives, smashing into human bodies almost always inflicted far more severe injuries than did the accidental harms previously caused by human beings themselves and, in most instances, even the injuries inflicted by horses or other farm animals in an earlier era. ${ }^{12}$ It is not surprising that this first technological revolution resulted in the most important transformation of tort law in American history.

Now, American society is in the midst of a similarly important set of technological changes. Autonomous vehicles, often referred to as driverless cars, and other forms of robotics controlled by artificial intelligence suggest that within a decade or less, much of the decisionmaking that results in personal injuries to others will be in the hands of machines, not humans. ${ }^{13}$ In the nineteenth century, machine force replaced human (and animal) force. Similarly, during the early twenty-first century, the decisions controlling machines will shift from humans to the machines themselves.

How will artificial intelligence and robotics change the tort law governing compensation for personal injuries? How should the law governing autonomous vehicles and other machines

\footnotetext{
${ }^{10}$ See Studenmaier, supra note 5 at 260 (noting the absence of technology as an appropriate topic of historical interpretation from a list that focused instead on racial minorities, families, and urban populations).

${ }^{11}$ But cf. Daniel Keats Citron, Cyber Civil Rights, 89 B.U.L. REv. 61, 62 (2009) (noting that "[n]ew technologies generate economic progress by reducing the costs of socially productive activities ... [but] often reduce the costs of socially destructive activities.").

${ }^{12}$ See infra notes 79-92, and accompanying text.

${ }^{13}$ See infra notes 342-392, and accompanying text.
} 
directed by artificial intelligence be changed? Neither the descriptive nor the normative question can be intelligently analyzed without an understanding of how and why American tort law responded to technological change in the past.

Informed by the history of how new technological waves affected tort law in the past, in this Article I present a simple descriptive model that suggests new technologies impact four variables that in turn alter tort law:

(1) the frequency of personal injuries caused by the technology;

(2) the severity of injuries caused by the new technology;

(3) the level of difficulty in proving liability; and

(4) the social utility of the new technology.

My focus here, with one exception, is how technology induces changes in the formal, articulated law of torts. I recognize that throughout the history of American tort law, novel technologies sometimes caused swells of tortiously-caused harms that were resolved through aggregate settlement procedures between "repeat players" both liability and damages issues that sometimes deviated from the formal, articulated rules of torts. ${ }^{15}$ I do describe the single example of how the settlement of routine automobile accident claims during recent decades, even in states that did not adopt formal no-fault systems, often echoes such an approach by awarding damages to injured claimants despite the fact that the strict application of the law of torts might suggest a different result and by valuing the damages awarded in a formulaic manner. ${ }^{16}$ Further, the scope of this Article is limited to the substantive issues of whether fault is required for liability and whether the claimant is able to recover the full measure of common-law damages or instead if recoverable damages are limited to economic losses or some portion thereof. I do not, for example, consider how new technologies led to

\footnotetext{
${ }^{14}$ See infra note 266 and accompanying text.

${ }^{15}$ See Samuel Issacharoff \& John Fabian Witt, The Inevitability of Aggregate Settlement: An Institutional Account of American Tort Law, 57 VAND. L. REV. 1571, 1588 (2004) (reporting that "such standardized claims practices ... tended to depart from what the formal law of torts might have provided in any individual case.").

${ }^{16}$ See infra notes 265-278, and accompanying text.
} 
innovative doctrines governing factual causation in mass product torts, such as market share liability. ${ }^{17}$

In Part I, I briefly describe technology in pre-industrial America and analyze why claims seeking compensation for personal injury were so rare even though most scholars conclude that the prevailing standard of liability was one of strict liability. There are few records of accidental injuries and claims for compensation, but what is known about technology and the law during this era enables me to offer a credible explanation for what occurred.

In Part II, I turn my attention to the mid-nineteenth century, the time of both the Industrial Revolution (especially the development of railroad networks), and the most dramatic transformation in the history of American tort law: the change from the ex-ante strict liability standard to the classical negligence regime. I examine the various competing explanations previously offered by legal historians and scholars to explain the change in liability standards. I conclude that technology in and of itself, rather than the class-based distributional consequences identified by Morton Horwitz and Lawrence Friedman, lay at the heart of the critical transformation from strict liability to negligence. ${ }^{18}$ Using the technology-caused factors affecting liability standards previously identified, I find that the most important factors causing the change were the increased aggregate liability facing railroads and other industries, caused largely by the increased severity of injuries resulting from the proliferation of new machinery, and the perceived social utility of new technologies. I also describe how other factors that legal historians and scholars identify as alternative explanations for either the increase in the

\footnotetext{
${ }^{17}$ See, e.g., Sindell v. Abbott Lab, 607 P.2d 924, 937 (Cal. 1980) (holding each DES-manufacturer liable for the portion of damages equivalent to its share of the relevant market for its product when plaintiff is unable to identify the particular defendant that manufactured the product causing her harm).

18 See infra notes 190-202, and accompanying text.
} 
frequency of claims ${ }^{19}$ or the emergence of the negligence regime ${ }^{20}$ are more accurately interpreted as secondary consequences of technological change.

In Part III, I describe three sets of legal changes that I attribute to the "aftershocks" of the Industrial Revolution. First, the proliferation of factories, which required the development of both railroad networks and industrial machinery, played an important role in the enactment of state workers' compensation statutes. ${ }^{21}$ Second, the proliferation of automobiles and the accidents they caused led to the formal adoption of no-fault compensation systems in a minority of states and routinized claims processing that sometimes resembled a no-fault system in other states. $^{22}$ Third, mass production factories combined with modern transportation systems to yield the mass consumer society, which, I argue, led in turn to the development of "strict" products liability. ${ }^{23}$

Part IV briefly outlines a descriptive model derived from the previous history and analysis, explaining the four variables that connect the technological advances to changes in substantive tort law. These variables include the frequency of personal injuries caused by the new wave of technology, the severity of those resulting injuries, the degree of difficulty victims face in proving their claims, and the social utility of the technological advances. I then test the model by applying it to past waves of technological change.

Part V looks to the future and anticipates the changes in accident compensation law likely to result from the imminent technological revolution in which decision-making by machines will control the force that causes personal injuries. I argue that technological advances, including

\footnotetext{
${ }^{19}$ See infra notes 95-125, 187, and accompanying text.

${ }^{20}$ See infra notes 173-189, and accompanying text.

${ }^{21}$ See infra notes 207-230, and accompanying text.

22 See infra notes 231-278, and accompanying text.

${ }^{23}$ See infra notes 279-330, and accompanying text.
} 
robotics, artificial intelligence, and particularly autonomous vehicles, will lead to the most important changes in American tort law since those of the mid-nineteenth century.

I then briefly conclude.

\section{Accidents and Claims in Pre-industrial America}

Pre-industrial America was a different world. In this Part, I begin by describing the paucity of significant accidental injuries that occurred in America before $1820 .{ }^{24}$ I then consider why even when accidental injuries did occur, they seldom led to legal claims for compensation. ${ }^{25}$ Finally, in those rare instances in which a claim reached court, I argue that the meager evidence suggests that the prevailing liability standard was one of strict liability. ${ }^{26}$

\section{A. Personal Injury Accidents in Pre-Industrial America}

Remarkably little is known about either accidental injuries in the United States before the mid-nineteenth century or claims for compensation resulting from such injuries. In later eras, the accidental harms that led to tort claims were most often caused by machinery. ${ }^{27}$ Carroll Pursell, a leading scholar of the history of technology, describes the technology that Europeans brought to the United States in the seventeenth century as "primarily a handicraft technology." 28 Pursell notes that "[m]ost tools were hand tools ... made of wood." 29 Well into the nineteenth century, the economy was almost exclusively an agrarian one, and machines were "the traditional tools of farming: the hoes, spades, scythes, reaping hooks, shovels, carts, harrows, and plows."30 Human

\footnotetext{
${ }^{24}$ See infra notes 27-34, and accompanying text.

${ }^{25}$ See infra notes 35-54, and accompanying text.

${ }^{26}$ See infra notes 55-64, and accompanying text.

27 See MANSEl G. BlaCKFORD \& K. Austin KerR, Business ENTERPRise IN AMERICAN HiSTORY 99 (2d ed. 1990) (observing that "industrialization changed the way goods were produced ... . [M] achines ... replaced handicraft labor").

${ }^{28}$ CARroll Pursell, The MaChine in AmericA: A Social HiSTORY OF AMERICA 10 (2d ed. 2007); see also BLACKFORD \& KERR, supra note 27, at 98 (reporting that "[b]efore the Industrial Revolution, men and women made yarn and cloth at home, with simple, hand-powered machinery").

${ }^{29}$ PURSELL, supra note 28, at 10.

${ }^{30} I d$. at 14 .
} 
beings provided both the force that operated the tools and the decision-making that directed their

use.

Accidental injuries no doubt occurred prior to the mid-nineteenth century, but we can only speculate as to how often they occurred. No government agency or insurance actuary contemporaneously compiled records of such accidents, but as any home-handyperson knows, even simple manual tools such as hammers, sometimes cause injuries. ${ }^{31}$ The bulk of accidents during the preindustrial era involved a single person and sometimes family members or close friends. ${ }^{32}$ As such, these accidents were decidedly different than their twenty-first-century analogs, which are perhaps best exemplified by random automobile accidents between strangers commuting on a Los Angeles expressway.

The earliest American legal opinions involving claims for personal injuries, issued between 1810 and 1840, describe a handful of examples of the subset of early accidental personal injuries where someone other than the victim or a family member can plausibly be asserted to have caused the accident. These accidents disproportionately involved injuries arising from transportation, still the most common source of tortious injuries. ${ }^{33}$ The injuries

\footnotetext{
${ }^{31}$ See Stephen D. Sugarman, Doing Away with Tort Law, 73 CALIF. L. Rev. 555, 592-93 n.166 (1985) (noting that most personal injuries occur in the household and do not result in filed claims).

32 See John Fabian Witt, The AcCidental RePUblic: CRipPled Workingmen, Destitute Widows, AND the REMAKING OF AMERICAN LAW 52-53 (2004) (reporting that "[d]uring the 1820s and 1830s, the shape of economic life in the North underwent a critical shift ... . New mills and factories ... separated production from the sphere of domestic life"); Kenneth S Abraham, The Common Law Prohibition on Party Testimony and the Development of Tort Liability, 95 VA. L. REV. 489, 498 (2009) (noting that "parties involved in accidents on family farms would typically have been close relatives, against whom suit would either have been economically pointless or barred by intrafamily immunity rules."); Gary T. Schwartz, Tort Law and the Economy in Nineteenth-Century America: A Reinterpretation, 90 YALE L.J. 1717, 1734 (1981) [hereinafter Tort Law and the Economy] (observing that "[i]n $1790, \ldots$ the vast majority of Americans lived and worked on family farms. In the urban towns, simple products were fabricated by artisans") (footnote omitted).

${ }^{33}$ See Thomas H. Cohen, U.S. DeP'T OF Justice, NCJ 206240, Tort Trials and Verdicts IN LaRge Counties 2001, at 2 tbl.1 (2004), https://www.bjs.gov/content/pub/pdf/ttvlc01.pdf (showing that 53.3\% of all tort trials in 2001 were automobile related; premises liability cases were a distant second at $16 \%$ ). Morton Horwitz refers to "collision cases" as "the first to involve joint actors." MORTON J. HORWITZ, THE TRANSFORMATION OF AMERICAN LAW, 1780-1860, 88, 95-96 (1977). A random sampling of written legal opinions in cases involving accidental personal injuries from this era includes injuries sustained by a stage-coach passenger when the negligent driver overturned the coach, Stokes v. Saltonstall, 38 U.S. 181, 190 (1839) (affirming judgment of liability); Ware v. Gay, (11 Pick.) 106, 112 (1831) (regarding personal injury caused by negligently maintained stagecoach); Lane v.

Crombie, 29 Mass. (12 Pick.) 177, 178 (1831) (regarding four-horse sleigh running over plaintiff); Ford v. Monroe,
} 
caused by these accidents, however, were likely distinguishable in important ways from those occurring even a half-century later. First, while it is only possible to speculate about the frequency of such accidental injuries, most were likely not as severe as injuries sustained in the late nineteenth and the twentieth century. The force or power that propelled the objects that impacted the victim's body and inflicted these injuries were either human or animal. In either event, they lacked the magnitude of force of the instrumentalities that would later inflict most accidental injuries, such as coal-fired steam locomotives or gasoline-powered automobiles.

Second, the human beings that accidentally inflicted the injuries in most instances were probably either the victim himself or family members or friends of the victim. They were not anonymous employees of large industrial enterprises that had access to significant resources to pay for the costs of the accidental injuries they had inflicted. ${ }^{34}$

\section{B. The Paucity of Personal Injury Claims in Pre-Industrial America}

Even when a victim experienced a personal injury of significant severity during the preindustrial period in the United States, it was unlikely that such injury would result in a legal claim seeking compensation. Legal historian John Fabian Witt observes that "[e]ighteenthcentury lawyers and judges in England and in the American colonies paid little attention to the problem of unintentional injury." 35 Several reasons explain this. First, as previously mentioned, the injurer often was a family member or a close friend. ${ }^{36}$ Most often, such individuals did not themselves possess the resources to make them attractive targets for claims seeking compensation. Corporations and other large-scale commercial enterprises, the "target

20 Wend. 210, 211 (N.Y. Sup. Ct. 1837) (driving a gig negligently resulted in death of a child), and those sustained by a driver when his horse and wagon fell through an opening of a bridge. See Shepherd v. Lincoln, 17 Wend. 250, 252 (N.Y. Sup. Ct. 1838) (affirming judgment of liability); cf. also, Hunt v. Pownal, 9 Vt. 411, 419 (1837) (holding defendant town liable for insufficiently maintained road that caused wagon to overturn).

${ }^{34}$ See infra notes $95-99$, and accompanying text.

${ }^{35}$ WITT, supra note 32, at 6.

${ }^{36}$ See supra notes 32,34 , and accompanying text. 
defendants" ${ }^{37}$ of later times, were rare. ${ }^{38}$ Further, it was not until the late nineteenth century that liability insurance became available in the United States. ${ }^{39}$ Indeed, liability insurance was believed to be against public policy, because it contributed to moral hazard by freeing a tortfeasor from the financial consequences of its tortious harms. ${ }^{40}$

The second reason that claims for personal injuries were rare was the witness disqualification rule. ${ }^{41}$ Unbelievable as it may seem today, until the 1840 s or later, the injured plaintiff and any other witnesses with an interest in the outcome, such as husbands and wives, were prohibited from testifying in court because of the witness disqualification rule. ${ }^{42}$

Obviously, this rule made it difficult or impossible for the plaintiff to find a witness to testify on her behalf in simple collision or workplace injury cases. ${ }^{43}$ The rule often posed less of a disadvantage to the defendant because in many cases the defendant was an entity such as a stagecoach or other transportation company. In this situation, many states interpreted the rule to allow the employees of the defendant to testify, even if the defendant itself would not have been able to do so. ${ }^{44}$ Further, plaintiffs were unable to testify about the damages that they were

\footnotetext{
${ }^{37}$ See Cornelius J. Peck, Washington's Partial Rejection and Modification of the Common Law Rule of Joint and Several Liability, 62 WASH. L. REV. 233, 238 (1987) (defining target defendants as tortfeasors selected as defendants based on their "financial responsibility and ability to pay. ..").

${ }^{38}$ See LAWRENCE M. FRIEDMAN, A History OF AMERICAN LAW 129 (3d ed. 2005) (noting that most corporations in the colonial period "were churches, charities, or cities or boroughs").

${ }^{39}$ See Kenneth S. Abraham, The Rise and Fall of Commercial Liability Insurance, 87 VA. L. REv. 85, 86 (2001) ("Until the second half of the nineteenth century, liability insurance would have been considered against public policy.").

${ }^{40} I d$.

${ }^{41}$ See Kenneth S. Abraham, supra note 32, at 490 (reporting that "between about 1600 and 1850, neither the plaintiff nor the defendant in a tort suit could testify in that suit"); Kenneth S. Abraham \& G. Edward White, The Transformation of the Civil Trial and the Emergence of American Tort Law, 59 ARIZ. L. REV. 431, 448-52 (2017) (describing the rule and its impact).

${ }^{42}$ See Abraham \& White, supra note 41, at 457-61 (describing repeal of the rule in various jurisdictions beginning in the 1840s and continuing until the 1890s); John Fabian Witt, Toward a New History of American Accident Law: Classical Tort Law and the Cooperative First-Party Insurance Movement, 114 HARV. L. REV. 690, 753-54 (describing the party disqualification rules and their origins).

${ }^{43}$ See Abraham \& White, supra note 41, at 433 (finding that "[f]ar fewer tort actions were brought at all, because often the only evidence available to the plaintiff was his or her own account of what had happened, and that was inadmissible.").

${ }^{44} I d$. at 462.
} 
uniquely able to testify about, such as pain and suffering. ${ }^{45}$ The net effect was to reduce the plaintiff's incentive to pursue litigation.

A third obstacle to bringing a personal injury claim in the eighteenth and early nineteenth century was that the new American states had adopted the then-contemporary common law of England with its intricate pleading requirements. ${ }^{46}$ Under the writ system, if a claimant's attorney chose the wrong cause of action, his claim would be dismissed with prejudice. ${ }^{47}$ In personal injury cases, the plaintiff's attorney's choice was typically between "trespass" or "trespass vi et armis" for immediate harms and "trespass on the case" for consequential harms. ${ }^{48}$ Leame v. Bray, ${ }^{49}$ a contemporaneous English case, illustrates a typical accident of the time and the intricacies of the trespass-case distinction. The defendant negligently drove his horse-drawn carriage into the plaintiff's carriage, causing plaintiff's driver to be thrown to the ground, the horses to run away with the plaintiff's carriage, and the plaintiff to jump for his life, fracturing his collarbone. The defendant contended that the injury was "consequential and not immediately flowing from the forcible act of the defendant" and therefore, the only proper remedy was an action for trespass on the case. ${ }^{50}$ The court, however, held that trespass was the proper tort because the defendant's application of force lead to a continuous set of activities that resulted in the plaintiff's injury. ${ }^{51}$ As one might imagine, the not-always-obvious application of these technical pleading requirements to cases involving accidental injury discouraged many attorneys from handling personal injury claims.

\footnotetext{
${ }^{45} I d$. at $470-71$.

${ }^{46}$ See HoRwITZ, supra note 33, at 28. See also, e.g., MD. CONST. DECL. RIGHTS art. 5 (guaranteeing "[t]hat the Inhabitants of Maryland are entitled to the Common Law of England").

${ }^{47}$ See Joseph H. Koffler \& Alison Reppy, HANDBOOK of COMMON LAW PleAding 434, 474 (1969) (explaining common law pleading).

${ }^{48}$ See Leame v. Bray, 3 East 593, 593, 102 Eng. Rep. 72, 724-25 (K.B. 1803) (stating that "where the injury is immediate on the act done, there trespass lies; but where it is not immediate on the act done, but consequential, there the remedy is in case.").

${ }^{49} \mathrm{Id}$.

${ }^{50} I d$.

${ }^{51} I d$.
} 
Finally, the contingent fee agreement, which today is the virtually universal means of compensating plaintiff's attorneys in personal injury cases was most often regarded as champerty, ${ }^{52}$ and therefore illegal, during the early decades of the nineteenth century. ${ }^{53}$ Then, as now, it is likely that few victims of personal injuries could afford the fees charged by plaintiff's attorneys out of their own pockets. By the late-nineteenth century, contingent fee agreements were widely viewed as legitimate, though still controversial. ${ }^{54}$

In summary, prior to the mid-nineteenth century, even when a victim sustained a serious, tortiously inflicted injury, a number of factors precluded the filing of claims in the vast majority of cases. These factors included the absence of liability insurance or defendants with sufficient resources to adequately compensate the victim, the complexity of common law pleading rules, the witness disqualification rule, and the prohibition of contingent fee agreements.

\section{The Strict Liability Standard in the Law of the Pre-Industrial Era}

Modern tort law often begins with the issue of whether liability for a personal injury is to be determined under a fault-based (negligence) standard or a no-fault (strict liability) standard. ${ }^{55}$ Until the mid-nineteenth century, however, judges, scholars, and lawyers simply did not evaluate potential liability in those terms. As described in the previous part, accidental personal injuries, particularly those between strangers, were rare. ${ }^{56}$ Even more unusual were legal claims for those injuries. ${ }^{57}$ When such claims were pursued, the focus of substantive law was on whether the

\footnotetext{
${ }^{52}$ See Peter Karsten, Enabling the Poor to Have Their Day in Court: The Sanctioning of Contingency Fee Contracts, A History to 1940, 47 DEPAUl L. REV. 231, 232 n.3 (1998) (citing BLACK's LAW DictionaRy 292 (4th ed. 1968)) (defining champerty as "[a] bargain by a stranger with a party to a suit, by which such third person undertakes to carry on the litigation at his own cost and risk, in consideration of receiving, if successful, a part of the proceeds or subject sought to be recovered.").

${ }^{53}$ See, e.g., Arden v. Patterson, 5 Johns. Ch. 44, 48 (N.Y. Ch. 1821) (Kent, Ch.) (stating that "[t]he purchase of a lawsuit by an attorney ... is champerty in its most odious form; and it ought equally to be condemned on principles of public policy."); see also Karsten, supra note 52, at 233-48 (1998)

${ }^{54}$ See Karsten, supra note 52, at 248-50.

${ }^{55}$ See, e.g., John C.P. Goldberg \& Benjamin C. Zipursky, The Strict Liability in Fault and the Fault in Strict Liability, 85 FORDHAM L. REV. 743, 744 (2014) (stating that "[n]o topic has received more attention in modern torts scholarship than the distinction between strict liability and fault-based liability.").

${ }^{56}$ See supra notes $27-31$, and accompanying text.

${ }^{57}$ See supra notes $35-54$, and accompanying text.
} 
claim should have been filed under the writ of trespass or the writ of trespass on the case, not whether the governing substantive law required proof of fault on the defendant's part. ${ }^{58}$ In short, characterizing the law governing personal injuries in the pre-Industrial Revolution era through the lens of later American tort law is fraught with ambiguity and uncertainty. ${ }^{59}$

Having acknowledged these challenges, most legal historians agree that the negligence regime that governed American tort law did not emerge until the mid-nineteenth century. Horwitz concludes that "[a]t the beginning of the nineteenth century there was a general private law presumption in favor of compensation, expressed by the oft-cited common law maxim sic utere. ${ }^{60}$ This strict or no-fault liability standard characterized the common law of England, ${ }^{61}$ which the American states continued to follow even after separation from the mother country. ${ }^{62}$ Horwitz argues that American common law decisions prior to the 1830s using the term "negligence" referred to cases involving the defendant's violation of a specific duty imposed by contract, ordinance, or statute, not an obligation to use reasonable care to prevent harm

\footnotetext{
${ }^{58}$ See supra notes $46-51$, and accompanying text.

${ }^{59}$ See Robert L. Rabin, The Historical Development of the Fault Principle: A Reinterpretation, 15 GA. L. REV. 925 , 925-26 (1981) (arguing that "[1]egal historians have ... scrutinize[ed] the cryptic opinions for traces of a 'fault' requirement in the early law of personal harms ... [but] the issue remains in doubt.") ${ }^{60}$ See HorwitZ, supra note 33, at 85; see also Charles O. Gregory, Trespass to Negligence to Absolute Liability, 37 VA. L. REV. 359, 370-72 (1951) (noting the presence of "liability for unintentionally caused harm" absent negligence).

${ }^{61}$ See, e.g., Weaver v. Ward, 80 Eng. Rep. 284, 284, Hobart 134, 135 (K. B, 1616) (stating that tort liability "tends to give damages according to hurt or loss ... except that it may be judged utterly without fault"); further explaining that the exception applies in narrow circumstances, e.g., "if a man by force take my hand and strike you, or ... that the plaintiff ran across his piece when he was discharging, or had set forth ... circumstances, so as it had appeared to the Court that it had been inevitable"). Similarly, in The Case of the Thorns, Y.B. 6 Edw. 4, fol. 7, pl. 18 (K.B. 1466), J. Brian stated in dicta:

And so if a man makes an assault upon me and I cannot avoid him, and he wants to beat me, and I in defence of myself raise my stick and strike him, and in raising it I hurt some man who is behind my back, this man will have an action against me. And yet it was lawful for me to raise my stick to defend myself, and it was against my will that I hurt him.
}

reprinted in COURTNEY STANHOPE KENNY, A SELECTION OF CASES ILLUSTRATIVE OF THE ENGLISH LAW OF TORT 379, 380-81 (1904). See also generally JOHN HAMILTON BAKER, AN INTRODUCTION TO ENGLISH LEGAL HISTORY 60-64, 402-05 (4th ed. 2002) (describing the English writ system); S.F.C. MILSOM, HISTORICAL FOUNDATIONS OF THE COMMON LAW 295-313 (2d ed. 1981) (describing the differences between trespass and trespass on the case). ${ }^{62}$ See, e.g., MD. CONST. DECL. RIGHTS art. 5 (providing "[t]hat the Inhabitants of Maryland are entitled to the Common Law of England ... as existed on July 4, 1776"); N.Y. CONST. art. XXXV (1777) (providing "that such parts of the common law of England ... and of the acts of the legislature of the colony of New York, as together did form the law of the said colony on the April 19, 1775, shall be and continue the law of this State"). 
generally. ${ }^{63}$ Legal historian Lawrence Friedman largely agrees with Horwitz's interpretation that

the negligence standard governing personal injury cases did not arise until the mid-nineteenth century:

All in all, tort law was not a highly developed field in 1776, or for a good many years thereafter. Not a single treatise on the law of torts was published before 1850, on either side of the Atlantic. Negligence was the merest dot on the law.... Existing tort law was simply not designed to deal with collision, derailments, exploding boilers, and similar calamities. ... American law had to work out on its own schemes to distribute the burden of railroad and steamboat accidents ... Tort law was new law in the nineteenth century. ${ }^{64}$

In summary, until the mid-nineteenth century, the best evidence is that liability for personal injury accidents was governed by a no-fault or strict liability standard. In spite of this, the aggregate liability of American businesses was extremely modest because the accidental injuries that did occur were not severe in most cases, and even serious injuries usually did not lead to legal claims for compensation.

\section{The First American Technological Revolution and the Development of Negligence}

New technologies profoundly changed the everyday life of many Americans during the nineteenth century. ${ }^{65}$ In the process, these technological changes altered both how personal injuries were inflicted and the severity of these injuries. ${ }^{66}$ Simultaneously, the manner in which the legal system handled claims for compensation for such injuries, including both the

\footnotetext{
${ }^{63}$ See HORWITZ, supra note 33, at 86-88. Gary Schwartz subsequently challenged several aspects of Horwitz's understanding of the development of negligence law during the mid-nineteenth century, including his contention that during the mid-nineteenth century, American tort law moved from a predominantly a no-fault or strict liability regime to one requiring negligence for liability. Schwartz, Tort Law and the Economy, supra note 32, at 1727-34. However, Schwartz later acknowledged that even his own historical account demonstrated that by the midnineteenth century, "the negligence term ... shed its turn-of-the-century ambiguity and ... acquired its status as a formal legal category." Gary T. Schwartz, The Character of Early American Tort Law, 36 UCLA L. REV. 641, 644, 678 (1989) [hereinafter The Character of Early American Tort Law] (acknowledging that "I am now inclined to avoid sweeping statements on the question of novelty versus evolution.").

${ }^{64}$ See FRIEDMAN, supra note 38, at 222-23.

${ }^{65}$ See infra notes 75-81, 88-90, and accompanying text.

${ }^{66}$ See infra notes 82, 91-92, and accompanying text.
} 
substantive principles of tort law governing such claims ${ }^{67}$ and the process for handling such claims,${ }^{68}$ were radically transformed. In this part, I explore the relationship between these technological and legal changes and consider whether the first was a cause of the second. ${ }^{69}$

\section{A. The Industrial Revolution, Railroads, and the Resulting Human Carnage}

In the century following American independence, citizens of the new republic typically greeted the Industrial Revolution and the technological changes it brought with considerable enthusiasm. ${ }^{70}$ Tenche Cox, an assistant of Alexander Hamilton's at the Department of Treasury described manufacturing technology as "the means of our POLITICAL SALVATION."71 By the early decades of the nineteenth century, most political leaders and journals lauded "the progress of the age." ${ }^{\text {72 }}$ Merritt Roe Smith, a leading historian of technology, writes, "Decade by decade the pace of technological change quickened-railroads, steamships, machine tools, telegraphy, structures of iron and steel, electricity — and with each decade the popular enthusiasm for "men of progress" and for their inventions grew."73 There was, however, a darker side to this unprecedented expansion of technology and industry. Witt writes that "[i]n the second half of the nineteenth century, the United States experienced an accident crisis like none the world had ever seen." $" 74$

The process of mechanizing industrial processes in the United States began in the second-half of the eighteenth century in textile mills ${ }^{75}$ and within two decades later in

\footnotetext{
${ }^{67}$ See infra notes 125-147, and accompanying text.

${ }^{68}$ See infra notes 107-124, and accompanying text.

${ }^{69}$ See infra notes 190-202, and accompanying text.

${ }^{70}$ See Merritt Roe Smith, Technological Determinism in American Culture, in DOES TECHNOLOGY DRIVE HISTORY?, supra note 5, at 2-13 (describing the identification of progress with technology in nineteenth-century America).

${ }^{71}$ Tench Coxe, An Address to an Assembly of the Friends of American Manufactures, Convened for the Purpose of Establishing a Society for the Encouragement of Manufactures and the Use Arts, Lecture at the University of Pennsylvania (Aug. 9, 1787), reprinted in THE PHILOSOPHY OF MANUFACTURES: EARLY DEBATES OVER InDUSTRIALIZATION IN THE UNited StATES 61-62 (M. B. Folsom \& S. D. Lubar eds., 1982)

${ }^{72}$ Smith, supra note 70 , at 5 .

${ }^{73} I d$.

${ }^{74}$ See Witt, supra note 42, at 694.

${ }^{75}$ See PURSELL, supra note 28, at 37-50 (describing the mechanization of the making of textiles); Schwartz, Tort Law and the Economy, supra note 32, at 1737 (describing the expansion of textile factories).
} 
ironworks. ${ }^{76}$ As Witt notes, however, "mills did not present ... the same dangers as the railroads and the mines" later would. ${ }^{77}$

Lewis Mumford, a preeminent social historian of technology, later described the Industrial Revolution as a transition from the "eotechnic" era, characterized by wood, water, and handicrafts, to a new "paleotechnic" world of steam, iron, and factories. ${ }^{78}$ He wrote that "[t]he specific triumph of the technical imagination rested on the ability to dissociate lifting power from the arm and create a crane ... [and] to dissociate work from the action of men and animals and create the water-mill ...."79 In textile production, the technological change was one from handpowered looms to those powered by water. Although the severity of injuries to workers in textile mills was not nearly as great as in some other nineteenth century industries, notably railroads and mining, 63 percent of the injuries occurring in textile mills in Massachusetts were caused by moving machinery and elevators. ${ }^{80}$ In the production of iron, the source of power soon shifted from water power to steam power and blast furnaces that used hot air produced by the burning of coal to heat the air injected into the hearth. ${ }^{81}$ In other words, with these technological advances, it was machines, and no longer humans or animals, that supplied the force or the intense heat that caused injuries to human beings. The force typically was much greater than that supplied during the pre-industrial era by humans and animals and, as a result, the severity of the injury was likely to be much greater.

\footnotetext{
${ }^{76}$ See PURSELL, supra note 28, at 50-63 (describing the mechanization of iron-making).

77 WITT, supra note 32, at 54-55.

${ }^{78}$ LEWIS MuMFORD, TECHNICS AND CIVILIZATION 151 (First Harbinger Books Edition 1963). See also BLACKFORD \& KERR, supra note 27, at 99 (identifying the fact that "new sources of power gained importance in the production process" as a key aspect of industrialization).

${ }^{79}$ MuMFORD, supra note 78, at 33; see also ERIK BRYNJOLFSSON \& ANDREW MCAFEE, THE SECOND MACHINE AGE: WORK, PROGRESS, AND PROSPERITY IN A TIME OF BRILliANT TECHNOLOGIES 6-7 (2014) (observing that "[t]he Industrial Revolution ... allowed us to overcome the limitations of muscle power, human and animal, and generate massive amounts of useful energy").

${ }^{80}$ See WITT, supra note 32, at 27.

${ }^{81}$ See PURSELL, supra note 28, at 55-56, 63.
} 
The mechanization of transportation, initially with steam-powered river boats and later, more prominently, with railroad locomotives, led to a dramatic explosion of accidental injuries. By 1850, 520 steamboats had been destroyed in accidents on American rivers, many due to steam-boiler explosions. ${ }^{82}$ These explosions and other accidents killed many individuals on and around the boats. ${ }^{83}$ The destructive impact of railroad steam locomotives, because of both their weight and force and the coal or wood-fueled fires that powered them, was even greater. The numbers of work-related injuries and deaths among railroads employees were simply staggering. ${ }^{84}$ Additionally, railroad passengers, ${ }^{85}$ those riding in horse-drawn vehicles that collided with trains, and individuals who walked alongside the tracks, frequently children, were often killed or severely injured. ${ }^{86}$ By the decade of the 1890 s, approximately six-thousand people died annually from railroad accidents, and an additional forty thousand were injured. ${ }^{87}$

The creation of the vast railroad network in the United States in turn facilitated the development of factories (manufacturing plants). ${ }^{88}$ Railroads hauled coal and other raw materials to the plants, and delivered their products to distant locations. ${ }^{89}$ Both the mining of coal and other minerals, and the manufacturing process itself became highly mechanized. ${ }^{90}$ As was the case with railroads, the constant interaction of workers, frequently women and children, with machinery in factories and mines caused the rates of death and serious injuries to skyrocket.

\footnotetext{
${ }^{82}$ See id. at $77-78$.

${ }^{83} \mathrm{Id}$.

${ }^{84}$ See JAMES W. ELY, JR., RAILROADS AND AMERICAN LAW 213 (2001) (noting that "[w]ork on railroads in the nineteenth century was extremely perilous. Rail workers ran a high risk of death or loss of limbs"); WITT, supra note 32, at 27 (reporting that in 1890, the death rate among railroad workers was 314 deaths per 100,000 workers; death rates among certain types of railroad workers were approximately three or four times as great).

${ }^{85}$ ELY, supra note 84, at 219.

${ }^{86} \mathrm{Id}$. at 221.

${ }^{87} \mathrm{Id}$. at 211.

${ }^{88}$ See BLACKFORD \& KERR, supra note 27, at 163 (observing that "[ $\mathrm{t}$ ] he creation of a national market through improvements in transportation and communication revolutionized the marketing and distribution of goods"); DAVID R. MEYER, THE ROOTS OF AMERICAN INDUSTRIALIZATION 156 (2003) (stating that "[r]ailroads offered forward linkages to industry by providing transport services; railroads could stimulate factory growth along rail lines ....").

${ }^{89}$ Id. at 155-56; ELY, supra note 84, at 229-31.

${ }^{90}$ See PURSELL, supra note 28, at 163-69.
} 
As an extreme example, Witt reports that "in the anthracite coal mines of Pennsylvania, ... each year during the 1850s and 1860s, six percent of the workforce was killed, six percent permanently crippled, and six percent seriously but temporarily disabled."91 More generally, during the last half of the nineteenth century, accidental death rates nearly doubled. ${ }^{92}$

\section{B. The Burgeoning Frequency of Personal Injury Claims}

As previously stated, few if any records exist that would allow scholars to quantify the frequency of personal injury claims in the early nineteenth century. ${ }^{93}$ It seems likely, however, that the number of claims increased significantly. ${ }^{94}$ In this part, I evaluate four factors that contributed to increasing the proportion of personal injury accidents caused by other parties that resulted in claims for compensation.

\section{The Emergence of Large Business Enterprises}

By the mid-nineteenth century, railroads and manufacturing firms had begun to emerge as the first large, modern corporations. ${ }^{95}$ By the last decades of the century, employers were large, bureaucratized corporations, and no longer firms and farms run by family members

\footnotetext{
${ }^{91}$ See WITT, supra note 32 , at 3.

92 Id. at 26.

93 See supra note 31 , and accompanying text.

94 Between 1820 and 1825, personal injury cases were few and far between even in developed states such as New York, Connecticut, and Pennsylvania. See, e.g., Gourley v. M’Allister, 5 Cow. 644 (N.Y. 1825); Lewis v. Babcock, 18 Johns. 443 (N.Y. Sup. Ct. 1821); and Overseers of Poor v. Bunn, 12 Serg. \& Rawle 292 (Pa. 1825) for examples of the scant number of opinions addressing issues in personal injury cases during the 1820 s. However, between 1890 and 1896, personal injury cases dominated the civil dockets in these states, with hundreds of cases related to injuries associated with the railroad industry. See, e.g., Donovan v. Hartford St. Ry. Co., 65 Conn. 201 (1894) (seeking recovery from railway company for injuries sustained when plaintiff was struck by a railway car); Birmingham v. Rochester City \& Brighton R.R. Co., 137 N.Y. 13 (1893) (pursuing personal injury action against a railway for a defect in the railway that injured plaintiff); Wood v. Pa. R. Co., 177 Pa. 306 (1896) (seeking recovery for personal injury sustained when a woman was killed by a train and plaintiff was struck by the corpse while waiting on the platform).

95 See Adolf A. Berle, Jr. \& Gardiner C. MeAns, The Modern Corporation And Private Property 11,13 (rev. ed. 1967) (1932) (stating that "the entrance" of the corporate enterprise "into the field of industry ... dates from the early Nineteenth Century"; further noting the evolving use of the corporate form in the textile and railroad industries during the ante-bellum period). See also JAMES WILLARD HURST, THE LEGITIMACY OF THE BUSINESS CORPORATION IN THE LAW OF THE UNITED STATES 1780-1970, at 17 (1970) (reporting that while two-thirds of special corporate charters in the last decades of the eighteenth century were concerned with transportation, that during the first half of the nineteenth century, more than forty percent of corporate charters in New Jersey and Wisconsin were for manufacturing and other business purposes).
} 
or close friends. ${ }^{96}$ Adolf Berle and Gardiner Means, in their foundational work on the American corporation, remark on the "mere size" and the "tremendous aggregations of property" that resulted from the emergence of the corporate structure. ${ }^{97}$ A corporate firm's capital and accumulated profits thus provided a ready fountain of compensation for injured employees. ${ }^{98}$ In addition, personal injury victims who had been reluctant to file claims against their employers, usually family members of close friends, ${ }^{99}$ experienced little hesitation in seeking compensation from faceless corporations. In short, the transition away from family-run and other small businesses to large corporations both provided an incentive for an injured employee or other victim to sue and eliminated a disincentive to sue.

\section{Liability Insurance}

Today, a very large percentage of the liabilities incurred by both corporations and individuals are paid by their liability insurers. ${ }^{100}$ However, for all intents and purposes, liability insurance was not invented until the late nineteenth century. ${ }^{101}$ By the middle of the century, marine and fire insurance policies often covered first-party property damage claims. ${ }^{102}$ Whether such policies covered harms to third-persons injured by the policyholder, however, had been

\footnotetext{
${ }^{96}$ See GLENN PORTER, THE RISE OF BIG BusinESS 1860-1920, at 21-23 (2d ed. 1992) (observing that "“[a]s large corporations began to build the elaborate bureaucracies necessary for their existence, ... business bean to lose its highly personal tone."); WITT, supra note 32, at 52-53 (noting the critical shift in production in the northern United States from the domestic sphere to large mills and factories).

${ }^{97}$ See BERLE \& MEANS, supra note 95, at 6; see also HURST, supra note 95, at 26 (stating that "the corporate form encouraged the muster or retention of resources by offering investors an assured frame of limited commitments").

${ }^{98}$ See BLACKFORD \& KERR, supra note 27, at 152-53 (reporting that "[b]y the 1850s, individual railroads had become the biggest business of the day. ... [T] he trunk-line railroads connecting the East with the Midwest were capitalized at from $\$ 17$ million to $\$ 35$ million each. ... Railroads continued to grow in size ... after the Civil War."); PORTER, supra note 96, at 33 (noting that by 1860, "numerous railroad companies had capital accounts of more than ten million dollars"); see generally Citron, supra note 11, at 114 (observing that "technological advances have created large, successful business entities ... that [t] hose harmed by new technologies see ... as fitting sources of compensation for their injuries").

${ }^{99}$ See supra note 32, and accompanying text.

${ }^{100}$ See Joni Hersch \& W. Kip Viscusi, Tort Liability Litigation Costs for Commercial Claims, 9 AM. L. \& ECON. REV. 330, 339, 360, 362 (2007).

${ }^{101}$ See Kenneth S. Abraham, Liability Insurance and Accident Prevention: The Evolution of an Idea, 64 MD. L. REV. 573,580 (2005) (stating that "[1]iability insurance was first marketed in the United States in the 1880s.").

${ }^{102} I d$. at 576.
} 
debated and litigated for decades. ${ }^{103}$ On one hand, marine insurance sometimes covered liability for collisions with other ships. ${ }^{104}$ It was here where insurance was for the first time understood as a pooling of the more or less inevitable risks of causing harm to others as a result of conducting one's business. ${ }^{105}$ On the other hand, the validity of liability insurance policies was questioned on the grounds that insuring against the consequences of negligence would lessen the deterrent effect of tort liability. ${ }^{106}$

It was not until the last decades of the nineteenth century that insurance for personal injuries began, initially in the form of first-party cooperative workingmen's insurance associations, often sponsored by trade unions. ${ }^{107}$ Commercial liability insurance, in the form of “employer's liability insurance[,] was first marketed ... in the 1880 s and designed to protect employers" from liability for claims filed by workers. ${ }^{108}$ Within a few years, policies such as these were expanded to cover liabilities owed to third parties other than the policyholder's employees. ${ }^{109}$

\section{The Abolition of the Witness Disqualification Rule}

As previously described, ${ }^{110}$ the witness disqualification rule was one of the factors that made it more difficult for plaintiffs to recover for personal injury claims before the midnineteenth century. Kenneth Abraham and G. Edward White report that beginning in 1848, states began to repeal the witness disqualification rule, and thirty-one states would do so by the 1880s. ${ }^{111}$

\footnotetext{
${ }^{103} \mathrm{Id}$. at $576-85$.

${ }^{104} \mathrm{Id}$. at 579.

105 See HoRWITZ, supra note 33, at 229.

106 See Abraham, Liability Insurance and Accident Prevention, supra note 101, at 580-85; see also HoRWITZ, supra note 33 , at 230 .

107 See WITT, supra note 32, at 76-84.

108 See Abraham, Liability Insurance and Accident Prevention, supra note 101, at 580.

${ }^{109}$ See Abraham, The Rise and Fall of Commercial Liability Insurance, supra note 39, at 87; Raymond N. Caverly, The Background of the Casualty and Bonding Business in the United States, Ins. Couns. J., Oct. 1939, at 62, 63-64. ${ }^{110}$ See supra notes 41-45, and accompanying text.

111 See Abraham \& White, supra note 41, at 460.
} 
The repeal of the party disqualification rule made it both more likely that injured parties would sue tortfeasors and more likely that they would recover. Abraham and White appear to offer the witness disqualification rule as an alternative explanation ${ }^{112}$ for the thesis expounded in this Part of the Article that modern negligence law replaced an earlier strict liability regime because courts realized that application of the law governing accident compensation ex ante would have impeded progress in the development of industry and transportation networks in the United States. ${ }^{113}$ Ultimately, however, they refrain from making this outright claim, and instead assert that the witness disqualification rule delayed the change from strict liability to negligence law for several decades after industrialization and the proliferation of railroads. ${ }^{114}$ Abraham and White's thesis, while convincing, does not refute the conclusion that over the long term, it was the onslaught of personal injury claims resulting from the Industrial Revolution that fundamentally transformed the law governing such claims from a strict liability standard to one based on negligence. ${ }^{115}$

\section{The Emergence of the First-Generation Specialized Personal Injury Bar}

The final factor contributing to the growth of personal injury law during the last half of the nineteenth century was the emergence of a group of attorneys specializing in the representation of personal injury claimants. As noted previously, in the early nineteenth century, courts almost always regarded the use of contingent fee arrangements by personal injury attorneys as unlawful. ${ }^{116}$ By the middle of the century, however, legislatures and courts in most

\footnotetext{
${ }^{112} I d$. at 436-37 (stating "that the proliferation of bodily injury cases that emerged ... in the last decades of the nineteenth century ... was connected to the emergence ... of industrial enterprises, mines, railroads, and trolleys ... is inadequate").

${ }^{113}$ See infra notes 190-202, and accompanying text.

${ }^{114}$ See Abraham \& White, supra note 41, at 475 (concluding that "the major spike in bodily injury claims did not take place contemporaneously with the growth of railroad networks, or even with the emergence of streetcar lines. It began to occur approximately one or two decades after railroads and streetcars had become the dominant modes of urban transportation. ... [W]itness disqualification rules, and their abolition, were important causal factors in the timing of tort law's emergence as a discrete common law subject.") (emphasis supplied).

${ }^{115}$ See infra notes 190-202, and accompanying text.

${ }^{116}$ See supra notes 52-53, and accompanying text.
} 
states had eliminated this prohibition. ${ }^{117}$ Beginning in the Jacksonian era, courts and legislatures were less inclined to prohibit contingent fees as champterty and viewed them instead as a vehicle to help those of limited means sue to vindicate their rights. ${ }^{118}$

The number of attorneys in New York City increased 49 percent during the single decade of the 1890s. ${ }^{119}$ Strikingly, the increase in attorneys who were the children of immigrants, whom Witt argues were more likely than other attorneys to specialize in representing personal injury victims, was 85 percent. ${ }^{120}$ The rate of increase in the number of plaintiffs' attorneys was even dramatically greater in some other urban centers. ${ }^{121}$ These urban personal injury attorneys employed "runners" who sought to arrive at an accident scene as soon as possible in order to sign the injured victim to a contract with the runner's employer, ${ }^{122}$ as well as "ward healers, ambulance drivers, police, telephone operators, and hospital staff" who helped "identify and recruit accident victims."123 Plaintiff's personal injury attorneys, with their immigrant backgrounds and sometimes-questionable business practices, created controversy with leaders of the bar and more established attorneys, particularly those representing businesses and insurance companies. $^{124}$

The relationship between the development of liability insurance, the abolition of the witness disqualification rule, and the emergence of the specialized plaintiff's injury bar, on one hand, and the increase in the frequency of personal injury claims and the liability exposure of large businesses, is a complicated one. Both the development of liability insurance and the expansion of the personal injury bar no doubt contributed to the increase in the number of

\footnotetext{
117 See Kartsen, supra note 36, at 240-41.

${ }^{118} \mathrm{Id}$.

119 See WITT, supra note 32, at 61.

${ }^{120} \mathrm{Id}$.

${ }^{121} I d$. (giving the example of Buffalo where "the growth in the number of lawyers who were the white children of immigrants was an astounding 170 percent from 1890 to 1900”)

${ }^{122} I d$. at 62.

${ }^{123}$ See Kartsen, supra note 52, at 257.

${ }^{124} \mathrm{Id}$. at $257-58$.
} 
claims, but these factors themselves resulted from the increase in the number of personal injuries that occurred.

The cause-and-effect relationship between the abolition of the witness disqualification rule and the increase in the number of personal injury claims is similarly bidirectional. The ability of the plaintiff and interested family members to testify regarding the causes of the accident certainly made it more likely that the injured victim would file suit. At the same time, it seems likely that the prospect that victims would suffer increasingly severe (especially) and more frequent injuries at the hands of anonymous, faceless corporations during the mid-nineteenth century contributed to the demise of that rule. None of these variables are truly independent; each is intertwined with others. What is clear is that all these changes, in whatever sequence, took place on the heels of industrialization and the development of the vast railroad network. ${ }^{125}$

\section{The Development of the Classical Negligence Regime}

Legal scholars usually agree that the law governing personal injury claims changed from a strict liability standard in 1820 to a negligence regime by 1870 . With a fair number of exceptions, that negligence regime continues to provide the basic framework for personal injury law in the twenty-first century. In this Part, I describe how the law had changed by the last decades of the nineteenth century. I also evaluate the competing theories for why this change took place.

\section{The Law Governing Liability for Personal Injuries by the late-Nineteenth Century}

Most legal historians and tort scholars agree that by the last decades of the nineteenth century, the law governing accidents was dramatically different and less hospitable to personal

\footnotetext{
125 See generally Balkin, supra note 1, at 50 ("The problem of physical injury is not simply a feature of essential characteristics of a technology. Rather, it arises from the way that a new technology interacts with a social and legal world already in place.”).
} 
injury claims than it had been during the early decades of the century. ${ }^{126}$ Horwitz describes the change in the law during the fifty-year period in dramatic terms: "[T]he rise of the negligence principle in America overthrew basic eighteenth century private law categories and led to a radical transformation ... in the theory of legal liability." 127

The differences between the law governing liability for personal injuries in the early nineteenth century and the corresponding law in the 1870 s constitute the most consequential changes in the history of American tort law. First, the injured victim was now required to prove that the defendant acted negligently (with fault). ${ }^{128}$ Horwitz identifies three distinct phases in the emergence of the negligence standard. ${ }^{129}$ During the first phase, in the early decades of the nineteenth century, courts began to view negligence as a matter of misfeasance instead of solely as a matter of nonfeasance, that is, the failure to fulfill a contractual or other autonomously ordained duty. In the second phase, beginning in the 1820 s, courts start to appreciate the distinction between "cause" and "fault." Even today, those not educated in the law often say that one driver in a car collision "caused" the accident, when what they mean is that the driver was the one at fault and not merely that her or his conduct was a necessary factual antecedent of the collision. Finally, in the third phase of the development of negligence, according to Horwitz, "beginning around 1840, the negligence doctrine breaks out of its rigid confinement to highway and ship collision cases and begins directly to challenge the presumption of compensation for

\footnotetext{
126 See, e.g., ELY, supra note 84, at 211-24; FRIEDMAN, supra note 38, at 223-25; HORWITZ, supra note 33, at 85, 95-101; WITT, supra note 32, at 43-48; Gregory, supra note 60, at 383-84.

${ }^{127}$ Horwitz, supra note 33, at 85. At least one leading scholar strongly disagreed with Horwitz's characterization of the change in the law as "a radical transformation," as well as many other aspects of Horwitz's thesis regarding the development of negligence. See Schwartz, Tort Law and the Economy in Nineteenth-Century America, supra note 32, at 1721 (arguing that "the nineteenth-century American negligence rule developed in a basically evolutionary way"); but cf., Schwartz, The Character of Early American Tort Law, supra note 63, at 678 (acknowledging, in a subsequent article, that "I am now inclined to avoid sweeping statements on the question of novelty versus evolution").

${ }^{128}$ See, e.g., Brown v. Kendall, 60 Mass. 292, 295-96 (1850) (holding that in a trespass action, the plaintiff could not recover without showing both that the defendant acted without due care and that the plaintiff acted with due care).

${ }^{129}$ See HoRwITZ, supra note 33, at 94-95.
} 
injury in [other] settled areas of the law." ${ }^{130}$ By the late nineteenth century, the requirement that the plaintiff prove negligence became particularly onerous, because most courts, at least in cases involving claims brought by injured employees, found that if the defendant-employer's conduct corresponded with the custom in its trade or business, this established that the defendant was not negligent as a matter of law. ${ }^{131}$

By the late nineteenth century, the negligence regime also included a trinity of affirmative defenses - the fellow servant rule, assumption of risk, and contributory negligencethat frequently prevented personal injury victims from recovering. ${ }^{132}$ During that era, the most important of these defenses was the fellow servant rule. ${ }^{133}$ In his infamous opinion in Farwell $v$. Boston \& Worcester Railroad Corp., ${ }^{134}$ Chief Justice Lemuel Shaw of the Massachusetts Supreme Judicial Court held that even though an employer was vicariously liable for the torts committed by his employees acting within the scope of employment in most instances, an injured employee could not recover from the employer for an injury caused by the tortious conduct of another employee. ${ }^{135}$ The proffered justification for the doctrine was that the injured employee was in a better position to be aware of the negligent conduct of his fellow employee than was the employer. ${ }^{136}$ While such a rule could arguably be justified "with a small preindustrial workshop in mind," it "rested on unrealistic assumptions and was not suitable" when applied to "dangerous equipment and a complex and compartmentalized workforce"137 of railroads and other large

\footnotetext{
${ }^{130} I d$. at 95 .

${ }^{131}$ E.g., Shadford v. Ann Arbor St. Ry., 69 N.W. 661, 663 (Mich. 1897) (finding no liability as a matter of law because the industrial tool "was one of a kind in general use throughout the country"); Allison Mfg. Co. v. McCormick, 12 A. 273, 275 (Pa. 1888) ("The general rule requires of the master that he provide materials and implements for the use of his servant such as are ordinarily used by persons in the same business, but he is not required to secure the best known materials").

132 See ELY, supra note 84, at 214-16, 221.

${ }^{133}$ See id. at 214-16; see also FRIEDMAN, supra note 38, at 223-25.

13445 Mass. (4 Met.) 49 (1842).

${ }^{135} \mathrm{Id}$. at 57 (holding that an employee "takes upon himself ... the perils arising from the carelessness and negligence of those who are in the same employment").

${ }^{136} \mathrm{Id}$. (reasoning that "perils arising from the carelessness and negligence of those ... in the same employment ... are perils which the servant is as likely to know, and against which he can as effectually guard, as the master.").

${ }^{137}$ ELY, supra note 84, at 215.
} 
corporations in the late nineteenth century. Within decades after the virtually universal adoption of the fellow-servant rule, some states repealed it by statute. ${ }^{138}$ Later, the Federal Employer's Liability Act, covering railroad employees among others, and state workers' compensation acts, abrogated the fellow-servant rule. ${ }^{139}$

The second of the common law defenses to the negligence action was "assumption of risk," which once again operated with particular harshness in cases brought by employees against their employers. ${ }^{140}$ The phrase itself denotes three separate ways that a defendant may negate the plaintiff's recovery. ${ }^{141}$ Two of these ways, together categorized as "implied assumption of risk," often served as important obstacles to recovery for personal injury victims, particularly workers, during the reign of classical negligence law. They also were often muddled. ${ }^{142}$ In the first instance (which sometimes was called "primary implied" assumption of risk), ${ }^{143}$ the employer was not liable if its workplace, despite posing dangers to workers, complied with a reasonable standard of care, often construed to mean that it complied with the custom of other similar employers. ${ }^{144}$ In the second sense of the term "assumption of risk," even if the employer were found to be negligent for subjecting the employee to unreasonable risks, it could still escape liability for its "negligence if the employee, by accepting or continuing in the employment with 'notice' of such negligence, 'assumed the risk.",145

\footnotetext{
${ }^{138} I d$. at $215-16$.

${ }^{139} I d$. at 216.

${ }^{140} \mathrm{Id}$.

${ }^{141}$ The first, that a defendant may disclaim liability through a contractual provision, see, e.g., 4 FOWLER V. HARPER ET AL., HARPER, JAMES AND GRAY ON TORTS § 21.6 (2007) (describing such contractual disclaimers and analyzing their validity), is not relevant here.

${ }^{142}$ See Tiller v. Atl. Coast Line R.R. 318 U.S. 54, 68 (1943) (Frankfurter, J., concurring) (describing “[t]he phrase [as] an excellent illustration of the extent to which uncritical use of words bedevils the law. A phrase begins life as a literary expression; its felicity leads to its lazy repetition; and repetition soon establishes it as a legal formula, undiscriminatingly used to express different and sometimes contradictory ideas.").

${ }^{143}$ See RESTATEMENT (THIRD) OF TORTS: APPORTIONMENT LIAB. $\$ 2$ cmt. j (AM. LAW INST. 2000). (describing the use of the label primary implied assumption of risk in the late nineteenth and early twentieth century).

${ }^{144}$ See also supra note 131 and accompanying text.

145 Tiller, 318 U.S. at 68-69 ((Frankfurter, J., concurring).
} 
The third and final affirmative defense to negligence was contributory negligence.

Today, in forty-six states, the victim's own lack of reasonable care that contributed to her injury will in many instances only reduce the plaintiff's recovery, but in the late nineteenth and early twentieth century, the plaintiff's contributory negligence served as a total bar to recovery. ${ }^{146}$ Thus, the momentary mental lapse of the driver of a vehicle approaching a railroad crossing or a worker waiting for a train to pass precluded recovery regardless of the level of egregiousness of the defendant's fault. ${ }^{147}$

In short, by the waning decades of the nineteenth century, there were far more barriers to the recovery by personal injury victims than had been present during the first decades of the century. The plaintiff now was required to prove fault. Even if it could be shown that the defendant, usually a railroad, an employer, or another business, was negligent, recovery was often prevented by one of the trinity of common law defenses, including the fellow-servant rule, assumption of risk, and contributory negligence.

\section{The Economic Explanation for the "Radical Transformation" of Nineteenth Century Tort Law}

The decidedly pro-defendant, substantial changes in the law governing liability for personal injuries during the nineteenth century are temporally correlated with the Industrial Revolution, especially the development of a vast railway network, and with the onslaught of injuries these new enterprises caused. The question remains whether this technological transformation of the economy in any way caused the equally dramatic changes in tort law. The

\footnotetext{
146 See Donald G. Gifford \& Christopher J. Robinette, Apportioning Liability in Maryland Tort Cases: Time to End Contributory Negligence and Joint and Several Liability, 73 MD. L. REV. 701, 723 (2014) (noting that all American jurisdictions treated contributory negligence as a total bar to recovery).

${ }^{147}$ See Bazzell v. Atchison, T. \& S. F. Ry. Co., 300 P. 1108 (Kan. 1931) (barring recovery for death of automobile driver struck by train that failed to sound bell and was obstructed by overgrown vegetation); Farmer v. Michigan Cent. Ry. Co. 58 N.W. 45 (Mich. 1894) (barring recovery for the death of a railroad worker struck by a boxcar while waiting to board his train); Summers v. Burdick, 13 Cal. Rptr. 68 (Ct. App. 1961) (refusing to hold automobile driver liable for striking visually impaired plaintiff).
} 
prevailing view among legal historians, notably Horwitz and Friedman, is that it did. ${ }^{148}$

Friedman attributes the cause of what he describes as the "explosion of tort law" that characterized the era to "the Industrial Revolution - the age of engines and machines." However, Schwartz explicitly disagrees with the "Horwitz thesis." 150 Moreover, a competing explanation for the emergence of the negligence regime contends that the new fault-based system emerged as a consequence of mid-nineteenth century political liberal thought. ${ }^{151}$ It is unclear, however, that these changes in liberal thought were truly independent of the Industrial Revolution and the resulting technological transformation of the economy. ${ }^{152}$

Probably the leading explanation for the dramatic changes in tort law during the midnineteenth century is that these changes facilitated industrial and railroad expansion. ${ }^{153}$ If the enterprises that emerged during the mid-nineteenth centuries had been held liable for the majority of the injuries and damages they caused, as they would have been under the strict liability principles that prevailed at the beginning of the century, so the theory goes, their businesses would have been less profitable and would not have been able to attract new capital. With the change to a system holding tortfeasors liable only for harms caused by their negligence, often interpreted to mean "non-customary" conduct, ${ }^{154}$ the liability exposure of businesses heavily invested in new technologies was almost assuredly substantially reduced. As a result, railroads, mines, and factories flourished. In effect, the change from a strict liability to a

\footnotetext{
148 See infra notes 153-159, and accompanying text.

${ }^{149}$ FRIEDMAN, supra note 38, at 223.

${ }^{150}$ See infra notes 160-165, and accompanying text.

151 See infra notes 173-185, and accompanying text.

152 See infra notes 187-190, and accompanying text.

${ }^{153}$ See Richard A. Posner, A Theory of Negligence, 1 J. LEGAL STUD. 29, 29 (1972) (describing this as the "orthodox view"); Schwartz, Tort Law and the Economy, supra note 32, at 1717 (describing this as the "prevailing view"); FRIEDMAN, supra note 38, at 223-24; HoRWITZ, supra note 33, at 99-100; Gregory, supra note 60, at 365 (stating that "many of our judges believed that the development of this young country under a system of private enterprise would be hindered and delayed as long as the element of chance exposed enterprisers to liability for the consequences of pure accident, without fault of some sort.").

154 See supra note 131, and accompanying text.
} 
negligence-based regime created a "subsidy" for railroads and other newly emerging

industries. ${ }^{155}$

The follow-up question is whether common law judges, including Chief Justice Lemuel

Shaw who decided both Brown v. Kendell and Farewell v. Boston \& Worcester Railroad Corp., knowingly and/or intentionally subsidized railroads and other businesses. Friedman answers the question this way:

But was Shaw also trying to subsidize the railroads? Perhaps not consciously. But he must have been aware how popular it was to encourage the development of railroads. Railroad building was popular, not only for people involved in what we would now call big business, but for the ordinary farmer or merchant, eager to get his goods to the market. It can hardly be a coincidence that so many emerging doctrines of tort law tilted toward railroads and other enterprises. There was no conspiracy. But there was, no doubt, a widespread consensus. ${ }^{156}$

Horwitz is much more explicit in calling the change in liability standards a "subsidy" for railroads and other emerging businesses and in attributing distributional motives to the judges responsible for these changes. He notes that state legislatures repeatedly had subsidized the development of canals during the 1820s and 1830s by granting monopolies or franchises and incurring debt, but without raising taxes. ${ }^{157}$ Substantial cash outlays to railroad corporations would have required increases in taxes. One might conjecture that by the 1830 s, entrepreneurs who stood to profit from the development of railroads and other industrial enterprises had begun to realize that increasing taxes to subsidize their projects was a two-edged sword. They may have feared that such a practice would lead at least some Jacksonian state legislatures to recognize the possibility of increasing taxes on the wealthy to benefit the less affluent. ${ }^{158}$ As

\footnotetext{
155 See HorwITZ, supra note 33, at 99-100 ("One of the most striking aspects of legal change during the antebellum period is the extent to which common law doctrines were transformed to create immunities from legal liability and thereby to provide substantial subsidies for those who undertook schemes of economic development."); but see Posner supra note 153, at 73 (stating that "I discern no systematic bias in the law of negligence as it was applied between 1875 and 1905 in favor of industrial growth and expansion, except insofar as the efficient use of resources may be thought to foster ... economic development. ... The rules of liability seem to have been broadly designed to bring about the efficient (cost-justified) level of accidents and safety.").

${ }^{156}$ FRIEDMAN, supra note 38, at 224-25.

157 See HoRWITZ, supra note 33, at 100.

${ }^{158} \mathrm{Id}$. at 101.
} 
Horwitz notes, "Change brought about through technical legal doctrine can more easily disguise underlying political choices. Subsidy through the tax system, by contrast, inevitably involves greater dangers of explicitly political conflict."159

Schwartz takes strong exception to the subsidy thesis and Horwitz's characterization of the changes in nineteenth century tort law as a "radical transformation." There are several significant threads to his critique. First, as previously described, Schwartz contends that, at least in the handful of states that he studied, elements of negligence law had emerged prior to $1830 .{ }^{160}$ However, his analysis did not include the dominant economic and legal hotspots of midnineteenth century America, such as New York, Massachusetts, or Pennsylvania. Further, Schwartz did not and could not convincingly argue that the predominant standard for liability during the later decades of the nineteenth century was anything other than a negligence standard accompanied by the affirmative defenses of contributory negligence, assumption of risk, and the fellow servant rule. Instead, he finds, more subtly, that although "[n]ineteenth-century tort law in New Hampshire and California emphasized negligence as the standard of liability ..., [c]ourts were reluctant to find that economic factors justified a defendant's risk-taking." 161 Similarly, he argues that the cases surveyed sometimes displayed a "negligence standard with a highly expansive quality"162 and although the New Hampshire and California supreme courts "from an early date accepted the traditional rule of contributory negligence as a complete defense[,] ... [they] were openly ambivalent about the rule."163 From these observations, he concludes that "the nineteenth-century American negligence rule developed in a basically evolutionary way."164

\footnotetext{
${ }^{159} \mathrm{Id}$. at $100-101$.

160 See supra note 127.

161 Schwartz, Tort Law and the Economy, supra note 32, at 1757.

${ }^{162}$ Id. at 1759. See also Schwartz, The Character of Early American Tort Law, supra note 63, at 679 ("Negligence can fairly be called the primary liability idea in nineteenth-century tort law, but it was by no means the exclusive liability standard').

${ }^{163}$ Schwartz, Tort Law and the Economy, supra note 32, at 1760.

${ }^{164} \mathrm{Id}$. at 1722 .
} 
Schwartz also directly rejects the thesis of Horwitz and Friedman that what drove the change to the negligence regime was a desire to subsidize railroads and other emerging industries. He chronicles several cases from California and New Hampshire in which the courts generously applied the doctrines of the negligence regime and enabled plaintiffs to recover against exactly these types of defendants. ${ }^{165}$

Assessing the debate between Horwitz and Friedman, on one hand, and Schwartz on the other hand, Ely concludes "that the knotty history of railroad tort liability does not fully support any unifying theory."166 He explicitly notes the 1853 Tennessee Supreme Court decision in Nashville \& Chattanooga Railroad Company v. Messino, ${ }^{167}$ in which the court indicates that its goals simultaneously included that "the most perfect safety should be secured" at the same time that "the rules of accountability should be reasonable, that men may not be deterred from devoting their time, capital, or energies to these very useful, and now almost indispensable enterprises."168 Similarly, after Professor (now Judge) Richard Posner surveyed tort opinions issued between 1875 and 1905, he concluded that "the rules of liability seem to have been broadly designed to bring about the efficient (cost-justified) level of accidents and safety... ."169 Of course, if the continued application of pre-1830s strict liability principles to newly emerging industries and railroads would have deterred industrial and railroad expansion at a level that was more than cost-justified, there is nothing in Posner's finding that is inconsistent with the Horwitz/Friedman thesis that the change in the law to the newly unfolding negligence regime was consciously designed to facilitate industrial expansion.

\footnotetext{
${ }^{165} I d$. at $1742-49$ (reporting the ways in which courts sometimes generously applied the doctrines of the negligence regime and enabled plaintiffs to recover).

166 ELY, supra note 84, at 212.

16733 Tenn. (1 Sneed) 220, 227 (1853) (affirming judgment for passenger negligently thrown from train).

${ }^{168}$ Id. at 225.

${ }^{169}$ Posner, supra note 153 , at 73.
} 
In tone, at least, Horwitz and, to a lesser extent, Friedman, may be overstating the revolutionary quality of the change in nineteenth century tort law. ${ }^{170}$ Yet the American law governing personal injury did change rather dramatically from a set of under-developed doctrines based on an English writ system that had changed only slightly over the course of several centuries, a body of law that had evolved to address entirely different harms. By the end of the nineteenth-century, many accident victims whose injuries were inflicted by the fruits of technological change were denied compensation on the grounds of tort doctrines that did not exist a half-century earlier. The law governing liability for personal injury accidents changed dramatically in the nineteenth century, and the pace of the change was radical compared to the grudging pace of change that characterized the previous centuries of English and American common law, ${ }^{171}$ a system where courts were presumed to follow precedents. ${ }^{172}$

\section{Alternative Explanations for Changes in Nineteenth-Century Tort Law}

G. Edward White ${ }^{173}$ and John Fabian Witt have both proffered alternative explanations to what Witt refers to as the Horwtiz/Friedman "materialist" 174 account of the rise of the negligence regime.

White's explanation focuses on "changes in intellectual thought" during the midnineteenth century and rejects the "subsidy thesis", but he nevertheless acknowledges the primary role of technological change as an instigator of the development of the negligence regime. He begins by arguing that "[i]t is misleading ... to speak of separate "tort" actions let alone standards

\footnotetext{
${ }^{170}$ In the first edition of A History of American Law, Friedman referred to the nineteenth-century negligence regime as "cruel" and as a "beast." LAWRENCE M. FRIEDMAN, A HISTORY OF AMERICAN LAW 426-27 (1st ed. 1973). Similarly, Gregory described the "ruthless" nature of the same body of law. Gregory, supra note 60, at 368. ${ }^{171}$ See John Fabian Witt, Contingency, Immanence, and Inevitability in the Law of Accidents, 1 J. TORT L. 1, 22 (2007).

${ }^{172}$ See, e.g., United States v. Drummond, 354 F.2d 132, 143 (2d Cir. 1965) ("The genius of the common law lies in the process of reasoned elaboration from past precedent"); Jill E. Fisch, Retroactivity and Legal Change: An Equilibrium Approach, 110 HARV. L. REV. 1055, 1107 (1997) (explaining that the requirement that common law courts' decisions be tied to precedents or "explicit text ... provides legitimacy to judge-made rules").

${ }^{173}$ G. EDWARD White, TORT LAW IN AMERICA: AN INTELLECTUAL HistORY 3-19 (2003).

${ }^{174}$ WITT, supra note 32 , at 8.
} 
of tort liability, before the nineteenth century."175 Like Horwitz, he views the "growth of negligence from the omission of a preexisting, specific duty owed to a limited class of persons to the violation of a generalized standard of care owed to all."176 The negligence regime, in his mind, "seems to have been an intellectual response to the increased numbers of accidents involving persons who had no preexisting relationship with one another_- "stranger cases."177 These accidents involving the interaction of strangers occurred far more frequently because of new technologies, particularly railroads. According to White, changes in intellectual thought combined with the carnage accidentally inflicted by new technologies to produce the negligence regime. White writes that "Americans became more focused on individual freedom ... and occupational mobility." ${ }^{178}$ As a result, "a new dynamic atomistic vision, which emphasized man's potential to alter the conditions under which he might exercise his capacity for achievement," emerged. ${ }^{179}$

Witt argues that the emergence of the negligence standard resulted from the influence of the contemporaneous prevalence of what is often referred to as "nineteenth-century political liberalism." ${ }^{180}$ John Stuart Mill articulated a basic premise of this philosophy when he wrote that "the only purpose for which power can be rightfully exercised over" another "is to prevent harm to others."181 As Witt notes, a judicial decision imposing liability was seen by courts and legal scholars of the time as an imposition on a defendant's liberty. ${ }^{182}$ These lawmakers, influenced by political liberalism, had no difficulty in holding a tortfeasor liable when it had been negligent and the plaintiff was free of fault because in that instance, the court's power was exercised "to prevent

\footnotetext{
175 WHITE, supra note 173 , at 14.

${ }^{176} \mathrm{Id}$. at 18

${ }^{177} \mathrm{Id}$. at 16 .

${ }^{178} I d$. at 4.

${ }^{179} \mathrm{Id}$.

${ }^{180}$ See WITT, supra note 32 , at 45-49.

${ }^{181}$ John Stuart Mill, On Liberty 13 (Stefan Collini ed., Cambridge Univ. Press 1989) (1859).

182 See WITT, supra note 32, at 46 (stating that "tort law marked the bounds of individuals' liberty").
} 
harm to others."183 However, the situation in which a defendant had caused harm to a victim

without any fault on the defendant's part posed a dilemma: how could they justify limiting the defendant's freedom when the defendant could not reasonably have avoided the harm? ${ }^{184}$ As

Oliver Wendell Holmes, Jr., wrote in 1881, “[T]he prevailing view is that the state's "cumbrous and expensive machinery ought not to be set in motion unless some clear benefit is to be derived from disturbing the status quo." 185 The wave of political liberalism led to an increased focused on fault and moral wrongdoing in the law, as well as in other aspects of American society. ${ }^{186}$

Political liberalism, however, is not an alternative, independent explanation for the rise of the negligence regime, but instead is itself, in least in part, a consequence of the Industrial Revolution. ${ }^{187}$ The Industrial Revolution nurtured the development of the class of entrepreneurs and managers who became the advocates for liberal political reform in the nineteenth century. ${ }^{188}$ Echoing the philosophy of Jeremy Bentham, mid-nineteenth century political liberalism saw infringements on the free market, whether through legislation or excessive liabilities imposed by common law courts, as threatening the security of property, social utility, and progress. ${ }^{189}$

Attributing the rise of negligence to political liberalism adds an intermediate step in the causal chain between technological advances and the dramatic changes in nineteenth-century tort law, but it does not eliminate the relationship.

\footnotetext{
${ }^{183} I d$.

${ }^{184} I d$. at 47 (explaining that "[a] negligence standard that held individuals liable for damages only when they failed to exercise reasonable care would allow individuals to act feely within their rights, without compromising those rights by charging them with the costs of harms that they could not reasonable avoid.") 185 Oliver Wendell Holmes, JR., The COMMON LAW 78 (Mark DeWolfe Howe ed., Belknap Press 1963) (1881). ${ }^{186}$ See, e.g., James Barr Ames, Law and Morals, 22 HARV. L. REV. 97, 113 (1908) (characterizing the emergence of the negligence regime as "bringing our system of law more and more into harmony with moral principles"); see also WITT, supra note 32, at 49 (suggesting that Thomas Cooley, the author of an influential torts treatise, may have been influenced by religiously inspired movements).

${ }^{187}$ See KARL POLYANYI, THE GREAT TRANSFORMATION 40 (1944) (arguing that "[t]he Industrial Revolution was merely the beginning of a revolution as extreme and radical as ever inflamed the minds of sectarians ... . "[O]nce elaborate machines ... were used for production ..., the idea of a self-regulating market was bound to take shape.").

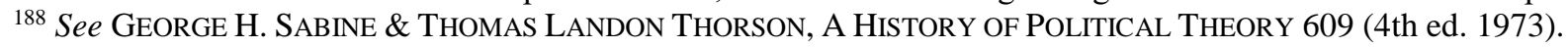
Sabine and Thorson attribute political liberalism's effect on the law to the philosophy of Jeremy Bentham, Id. at 614-22 (Mark DeWolfe Howe ed., Belknap Press 1963) (1881).

${ }^{189}$ Id. at 609.
} 


\section{Technology as the Cause of the Classical Negligence Regime}

By the 1870s, as Witt describes it, the United States was experiencing an unprecedented accidental injury crisis ${ }^{190}$ that led to the first major transformation of American tort law. This dramatic change, from a strict liability standard to the negligence regime, resulted from a judicial weighing of the aggregate liability facing railroads and other industrial defendants against the social utility of such industries. The increase in aggregate liability was a product of the increased severity of personal injury accidents during the industrial era, ${ }^{191}$ a possible increase in the frequency of such accidents, ${ }^{192}$ and several factors making it easier for plaintiffs to prove their claims, each of which was itself a consequence of new technologies. The witness disqualification rule was abrogated ${ }^{193}$ and a professional plaintiff's personal injury bar emerged for the first time. ${ }^{194}$ Further, the development of large-scale corporations and liability insurance $^{195}$ afforded victims a source of meaningful compensation, as well as an incentive for attorneys retained on a contingent-fee basis to pursue their claims. Each of these developments, however, themselves resulted from the increase in the liability exposure of railroads and other industrial defendants. ${ }^{196}$

In addition, to the threatened increase in aggregate liability, the decisive variable responsible for the transformation from the pre-industrial strict liability rules to the negligence regime that emerged during the mid-nineteenth century was the perceived (and genuine) social utility of railroads and other industrial enterprises. ${ }^{197}$ At a time when Americans were enthusiastically supportive of railroads and other new technologies, the application of tort law

\footnotetext{
${ }^{190}$ See Witt, supra note 42, at 694.

${ }^{191}$ See supra notes 82-87, 91-92, and accompanying text.

192 See supra notes 82-92, and accompanying text.

${ }^{193}$ See supra notes 110-115 and accompanying text.

${ }^{194}$ See supra notes 116-124 and accompanying text.

195 See supra notes 95-109 and accompanying text.

${ }^{196}$ See supra note 125 and accompanying text.

197 See supra notes 70-73, and accompanying text.
} 
that existed at the turn of the nineteenth century likely would have discouraged the capital contributions necessary to expand these new technologies.

Compelling evidence indicates that by late-nineteenth century, the substantive law governing claims for personal injuries was more daunting to the personal injury victim that it had been a half-century earlier. Plaintiffs were required to prove negligence. ${ }^{198}$ Correspondence with custom by defendants either established compliance with due care as a matter of law or at least was strong evidence of a lack of negligence. ${ }^{199}$ Perhaps most importantly, many victims, particularly employees of railroads and other industrial enterprises, were barred from recovery by the fellow-servant rule, ${ }^{200}$ assumption of risk, ${ }^{201}$ and contributory negligence. ${ }^{202}$ These changes in substantive law, the most important changes in the law governing liability for personal injuries in at least five hundred years, occurred during the same half-century as did the most important changes in how technology affected ordinary human life that had occurred at any point in human history to that time.

\section{The Legal Aftershocks of the Industrial Revolution}

The most significant transformation of American tort law was the victory of the negligence regime during the mid-nineteenth century. In the early twenty-first century, American society faces the prospect of the second American tort revolution: the substantive law's response to autonomous vehicles, robotics, and artificial intelligence. ${ }^{203}$ During the intervening period of more than a century, American accident compensation law also witnessed additional significant changes: notably, the enactment of the workers' compensation system, ${ }^{204}$ the routinized processing of claims arising from automobile accidents applying informal rules

\footnotetext{
198 See supra notes 128-131, and accompanying text.

199 See supra note 137 and accompanying text.

200 See supra notes 133-139, and accompanying text.

${ }^{201}$ See supra notes 140-145, and accompanying text.

202 See supra notes 146-147, and accompanying text.

${ }^{203}$ See infra notes 342-392, and accompanying text.

${ }^{204}$ See infra notes 207-230, and accompanying text.
} 
that often conflicted with the formal law, ${ }^{205}$ and the rise (and fall) of strict products liability, each of which can be traced to changes in the economic structure resulting from technological development. ${ }^{206}$ In this Part, I trace the origins of these legal developments to aftershocks of the Industrial Revolution.

\section{A. The Factory System and the Enactment of Workers' Compensation}

The economic changes resulting from the "second Industrial Revolution"207 were far from completed by the end of the nineteenth century. Even as late as the 1870s, most American families remained largely unaffected by the technological changes of the nineteenth century. Most Americans continued to wear clothing handcrafted at home and eat food that they had raised. ${ }^{208}$ Horses, not machines, provided most transportation. ${ }^{209}$ Appliances such as refrigerators and gas or electric powered stoves were still far in the future.

As previously noted, ${ }^{210}$ however, the propagation of railroads and other technological developments, paved the way for the development of factories. ${ }^{211}$ Railroads shipped raw materials to factories and in turn, and more importantly, distributed their products to a widespread national market. Without railroads or a similar transportation system, mass production of consumer goods on the assembly line would have been impossible.

\footnotetext{
205 See infra notes 231-278, and accompanying text.

${ }^{206}$ See infra notes 279-341, and accompanying text.

${ }^{207}$ See Robert J. Gordon, The Rise AND FALl OF AMERICAN GROWTH: THE U.S. STANDARD OF LIVING SINCE THE CIVIL WAR 31 (2016) (labelling the technological changes beginning in 1870 and continuing into the early decades of the twentieth century as the "Second Industrial Revolution").

${ }^{208}$ Id. at 39-43 (describing prevalence of home production of clothing and food in 1870).

${ }^{209} I d$. at 48.

${ }^{210}$ See supra notes 88-89, and accompanying text.

${ }^{211}$ See Jeremy Atack et al., Railroads and the Rise of the Factory: Evidence for the United States, 1850-70, at 6, (National Bureau of Economic Research Working Paper No. 14410) (Oct. 2008), http://www.nber.org/papers/w14410.pdf. (reporting empirical findings that "the coming of the railroad was a causal factor in the rise of factories.").
} 
Simultaneously with the proliferation of factories, railroad networks continued to expand ${ }^{212}$ and machinery became a ubiquitous feature of American life, particularly in workplaces. ${ }^{213}$

As described in Part II, the negligence regime, particularly the application of its fellowservant rule, made it exceptionally difficult for workers to recover for injuries sustained during their employment. By the turn of the twentieth century, this situation was intolerable to workers, their unions, and social reformers. ${ }^{214}$ At the same time, corporate employers feared that the onerous consequences of the fellow-servant rule doomed it and that its abrogation within the common-law system would result in greatly expanded aggregate corporate liability. ${ }^{215}$ American corporations increasingly feared massive common-law liability exposure as liability insurance and accumulated profits made them attractive targets ${ }^{216}$ from the new professionalized plaintiff's bar. $^{217}$

The result, in the second decade of the twentieth century, was the widespread enactment of workers' compensation statutes. ${ }^{218}$ Under workers' compensation, workers injured in the course of employment recovered benefits without proving fault on the employer's part. ${ }^{219}$ Further, and more importantly, the statutes eliminated the affirmative defenses of the fellowservant rule, assumption of risk, and contributory negligence. ${ }^{220}$ However, workers'

\footnotetext{
${ }^{212}$ See PURSELL, supra note 28, at 175 (stating that "[i]n the years after the Civil War, it was the railroad that colonized the West").

${ }^{213}$ See PORTER, supra note 96, at 44-45 (noting the importance of "the appearance of an array of technological advances in manufacturing technology" as a cause of "the coming of big business").

${ }^{214}$ See Price V. Fishback \& Shawn Everett Kantor, A Prelude To The Welfare State: The Origins of WORKERS' COMPENSATION (2000) (describing the dissatisfaction of social reformers like Crystal Eastman and the American Association of Labor Legislation with the negligence liability system); WITT, supra note 32, at 130-32 (describing impact of Eastman's work).

${ }^{215}$ See WITT, supra note 32, at 67 (describing statutory and judicial abrogation of fellow-servant doctrine in period preceding adoption of workers' compensation statutes).

${ }^{216}$ See supra notes 95-99, and accompanying text.

${ }^{217}$ See supra notes 116-124, and accompanying text.

${ }^{218}$ FISHBACK \& KANTOR, supra note 214, at 54 (stating that "[b]etween 1911 and 1921, forty-three states adopted workers' compensation laws at the behest of political coalitions combining workers, employers, and insurers").

${ }^{219}$ See HARPER ET AL., supra note 141, \$11.2 (describing workers' compensation); Richard A. Epstein, The Historical Origins and Economic Structure of Workers' Compensation Law, 16 GA. L. REV. 775, 797-800 (1982) (describing abolition of both fault as a requirement of liability and fault-based affirmative defenses).

${ }^{220}$ See HARPER ET AL., supra note 141, §11.2; Epstein, supra note 219, at 798. Similarly, the Federal Employers' Liability Act (FELA), 45 U.S.C. $\S \S 51-60$ (2012), enacted in 1908, governed injuries sustained by railroad workers. An injured railroad worker must prove negligence on the part of the employer to recover, but the act eliminated the
} 
compensation acts eliminated the right of injured workers to have a jury adjudicate their claims, and compensation under the acts was severely limited. ${ }^{221}$ Claimants received no compensation for noneconomic injuries ("pain and suffering"), recovery for loss of income was significantly limited, ${ }^{222}$ and future medical expenses were paid as they were incurred. It was also believed that workers' compensation would substantially reduce the transaction costs involved in adjudicating claims. ${ }^{223}$ Administrative hearings replaced jury trials, ${ }^{224}$ and attorney fees for claimants' attorneys were strictly limited. ${ }^{225}$

The enactment of workers' compensation statutes and the Federal Employers Liability Act are most accurately interpreted as necessary counter moves to the development of the classical negligence regime that was not fully satisfactory to either employers or to their workers. The critical variable for injured workers and their union representatives was the increased difficulty of proving the employer's negligence in an industrialized workplace dominated by machine technology. ${ }^{226}$ Businesses, however, feared that any return to a strict-liability common law system in an attempt to ease proof of liability would increase their aggregate liability

fellow-servant rule and replaced contributory negligence with comparative negligence. The defense of assumption of risk was later eliminated in actions under FELA.

${ }^{221}$ See 3 HARPER ET AL., supra note 141, §11.2.

${ }^{222} I d$.

${ }^{223}$ See FISHBACK \& KANTOR, supra note 214, at 11-12 (before the implementation of the workers' compensation system, "Attorney's fees, court costs, and the administrative costs of insurance left a 40 to 60 percent gap between what employers paid out for postaccident compensation and what workers ultimately received;" arguing, however, that because "most cases under negligence liability were settled outside the courts, it is very difficult to determine even whether administrative costs per injury ... declined").

${ }^{224}$ See 3 HARPER ET AL., supra note 141, §11.2; Epstein, supra note 219, at 801.

${ }^{225}$ FISHBACK \& KANTOR, supra note 214, at 228 (reporting that "[a]t most, 5 percent of the total amount that workers received went to lawyers under workers' compensation").

${ }^{226}$ See WITT, supra note 32, at 128 (noting that early explanations of the origins of workers' compensation saw it as "an unambiguous advance from a stingy nineteenth-century law of employers' liability to a regime organized around serving the needs of injury workers."). In his comprehensive and insightful consideration of the origins of workers' compensation, Witt emphasizes the contributions of lawyer-journalist Crystal Eastman and how she shifted the focus on the effects of workplace injuries from the direct victims themselves to those suffered by the members of the workers' families. Id. at 129-32. Witt also notes that "national labor leaders ... generally supported workmen's compensation legislation, but often in ways that hinted at a deep ambivalence." Id. at 147. Social reformers saw the enactment of workers' compensation as the beginning of a movement toward more widespread social reform legislation, such as social security, unemployment insurance, and national health insurance. Id. at 149-50; see also Jeremiah Smith, Sequel to Workmen's Compensation Acts, 27 HARV. L. REV. 344, 363-65 (1914) (suggesting that in the wake of the adoption of workers' compensation, broader social legislation might be enacted). 
exposure. These concerns likely would cause them to cut-back or slowdown their business activities that continued to be perceived as offering great social utility. ${ }^{227}$

The solution, workers' compensation, dramatically reduced the difficulty of proving the prerequisites of liability by abrogating the need to prove fault and in the process reduced transaction costs by replacing common-law juries with professional administrative agencies. ${ }^{228}$ At the same time, the workers' compensation system moderated the feared increase in the liability exposure facing employers and made it more predictable. The severity of paid claims was reduced by disallowing recovery for noneconomic damages, capping recovery for economic losses, and placing responsibility for assessing the amount of damages to be paid with administrative agencies instead of common law juries.

Following the adoption of workers' compensation, the frequency of claims for personal injuries resulting from employment greatly increased. ${ }^{229}$ The increase in claims was so dramatic that employers' aggregate liability exposure increased, even though the average amount of paid claims was reduced because of capped benefits and the lack of compensation for noneconomic damages. With that increase, however, employers received assurance that they would not be slammed with a huge verdict in any single case and that future changes in the common law, such as the abolition of the fellow-servant rule, would not greatly increase their liability exposure for workplace accidents. ${ }^{230}$

\footnotetext{
${ }^{227}$ See WITT, supra note 32, at 128 (noting that [b]y the late 1960s, [h]istorians in the then-ascendant corporateliberal school explained the enactment of compensation statutes as a novel gambit by employers to reduce and standardize the mounting costs of jury awards under the common law of employers' liability"). Witt observes that sophisticated employers (usually larger corporations) began to accept the notion that industrial accidents were "a necessary hazard of work" that could be managed and reduced through the application of scientific-management principles). Id. at 243-45.

${ }^{228}$ See Don DeweEs et Al., EXPloring the Domain OF ACCIDENT LaW: TAKING THE FACTS SERIOUSLY 393-94 (1996) (stating that the workers' compensation system "spend approximately $15-20 \%$ of the total costs of claims on administration," while "[f]or the tort system, ... about 50\%-55\% of the total costs of claims comprises administration costs.").

${ }^{229}$ WITT, supra note 32, at 191 (noting that "[a]s early as 1917, workmen's compensation systems around the country received in excess of 350,000 claims per year").

${ }^{230}$ See supra note 220 and accompanying text.
} 


\section{B. The "Evil Deity's"231 Gift of the Automobile}

The widespread ownership and use of automobiles dramatically increased the scope of the accidental-injury problem in the United States. Jonathan Simon writes that "[i]n 1919 the automobile was still largely seen as a luxury item,” but “[b]y 1929, ... it was visibly transforming American life. ${ }^{232}$ More than 3,735,000 new automobiles were sold in 1925, and by the end of the decade, one-half of American households owned an automobile. ${ }^{233}$ The social utility of the widespread use of the automobile was obvious. As Nora Engstrom observes, "automobiles are central to the American way of life, 'permitting an impatient people to conquer space and time.' ",234

With the advent of the automobile, the number of machines capable of inflicting serious personal injuries dramatically increased, and these machines and their "attendant carnage" were "broadly distributed across the social landscape."235 Writing in the Columbia Law Review in 1925, Robert Marx observed:

Formerly, when horse drawn vehicles, slow in movement and few in number, were the principal means of transportation, there was comparatively little danger in the use of the streets. But the increasing use and speed of automobiles have made our streets more dangerous than our factories and are causing a greater loss of life and a greater number of casualties or losses than in the World War. ${ }^{236}$

The automobile fatality rate increased five-hundred percent between 1913 and $1931 .^{237}$

Thirty-three thousand people died in automobile accidents in $1930,{ }^{238}$ a number only slightly less

\footnotetext{
${ }^{231}$ Guido Calabresi famously asks his students whether they would trade far greater convenience and speed for 50,000 lives annually. Then he reveals that the subject of his query is the automobile. GUIDO CALABRESI, IDEALS, BELIEFS, ATTITUDES, AND THE LAW 1-7 (1985).

232 Jonathan Simon, Driving Governmentality: Automobile Accidents, Insurance, and the Challenge to Social Order in the Inter-War Years, 1919 to 1941, 4 CONN. INS. L.J. 521, 530 (1998).

${ }^{233} I d$. at 531.

${ }^{234}$ Nora Freeman Engstrom, An Alternative Explanation for No-Fault's “Demise,” 61 DEPAUL L. REV. 303,303 (2012) (quoting JERRY L. MASHAW \& DAVID L. HARFST, THE STRUGGLE FOR AUTO SAFETY ix (1990)).

235 Simon, supra note 232, at 525.

${ }^{236}$ Robert S. Marx, Compulsory Compensation Insurance, 25 CoLUM. L. REV. 164, 167 (1925). See also Simon, supra note 232, at 527 (observing that "[1]ike the factory machine, the automobile was capable of mutilating the human body in a way which ... horrified [the] public.").

${ }^{237}$ REPORT BY THE COMMITTEE TO STUdY COMPENSATION FOR AUTOMOBILE ACCIDENT 17 (1932) [hereinafter COLUMBIA REPORT].

${ }^{238} I d$.
} 
than the thirty-five thousand that died in 2010, despite the dramatic increase during that period of time in both the number of automobiles and the number of miles driven. ${ }^{239}$ In 1929 , automobile accidents accounted for twenty-nine percent of all accidental deaths, as compared with seven percent caused by railroad accidents. ${ }^{240}$ The distribution of the severity of these claims included many serious injuries. ${ }^{241}$ Even today, a majority of all torts claims arise from automobile accidents, as does three-quarters of the aggregate compensatory payments for tort claims. ${ }^{242}$ Just as is the case today, in the 1930s, few owners and operators of automobile possess the financial resources to enable them to personally compensate those seriously injured in traffic accidents. ${ }^{243}$ Unlike in the nineteenth century when large industrial and transportation enterprises were liable for the torts committed by their employees, ${ }^{244}$ the more limited resources of most automobile owners posed the threat that there would be no source of funds to compensate victims of automobile accidents. In the automobile context, the primary objective of liability insurance became to provide a source of compensation for the injured victim rather than to protect the assets of the tortfeasor. ${ }^{245}$ Unfortunately, only twenty-seven percent of all automobiles registered in 1929 had liability insurance coverage. ${ }^{246}$ At the same time, however, states were beginning to adopt "financial responsibility laws" that required automobile owners to either purchase insurance or to provide proof that they had sufficient financial resources to pay

\footnotetext{
239 See Engstrom, supra note 234, at 303.

${ }^{240}$ See Simon, supra note 232, at 541 tbl 2.

${ }^{241}$ See Christopher J. Robinette, Two Roads Diverge for Civil Recourse Theory, 88 IND. L.J. 543, 556-58 (2013) (noting slotting of cases into small, more routine ones and larger cases).

${ }^{242}$ See JAMES M. ANDERSON ET AL., THE U.S. EXPERIENCE WITH No-FAult AutOMOBILE InSURANCE 1 (2010), http://www.rand.org/content/dam/rand/pubs/monographs/2010/RAND MG860.pdf.

${ }^{243}$ See COLUMBIA REPORT, supra note 237, at 81, 90 (finding that in the cases of permanent disability, "[o]nly 4\% of the insured cases were not paid while of the not insured cases $79 \%$ received nothing"; further noting that in cases involving fatalities, "insured cases payments which are sufficient to cover the funeral and medical losses were received in $77 \%$ of the cases" and "[f]or the not insured cases losses were covered by the payment received in only $7 \%$ of the cases"); Simon, supra note 232, at 555 (noting that [t] he owner's liability policy was typically the only available source of assets to pay any judgment").

${ }^{244}$ See supra notes 95-99, and accompanying text.

${ }^{245}$ See Wheeler v. O’Connell, 9 N.E.2d 544, 546 (Mass. 1937) (stating that the purpose of liability insurance "is not ... to protect the owner ... from loss, but rather is to provide compensation to persons injured").

${ }^{246}$ See Simon, supra note 232, at 561.
} 
claims. $^{247}$ By 1935 a majority of states had enacted such statutes. ${ }^{248}$ Today forty-nine states mandate that automobile owners carry liability insurance, and the remaining state has a financial responsibility law. ${ }^{249}$

Following closely on the heels of the adoption of workers' compensation systems, the automobile-accident problem suggested the adoption of a no-fault compensation system. In addition to the reality that insurance usually provided the only source of funds for compensation, "[o]btaining agreement on what constituted careless behavior [and] proving what had happened" posed challenges to the traditional tort system. ${ }^{250}$ Simon observes that " $[\mathrm{t}]$ he power and speed of motorized machinery ... simply outstripped the capacity of even careful persons to guard against mishap, and magnified the consequences of lapses of care beyond moral recognition." 251 Additionally, the limits of the owner's insurance policy functionally capped recovery. Most but not all injuries were relatively minor. The limited size of many claims suggested finding a less costly and time-consuming resolution of claims.

As early as 1932, a distinguished group of judges, lawyers, and law professors, assisted by two professional sociologists, proposed a no-fault compensation plan that generally is referred to as the "the Columbia Plan," 252 which echoed the structure of workers" compensation-a nofault process providing limited benefits through an administrative compensation system. However, it was not until Robert Keeton and Jeffrey O'Connell proposed a no-fault system that retained elements of traditional tort law in $1965^{253}$ that states began to adopt automobile no fault. The basic plan, known as Personal Injury Protection (PIP), mandated that each auto owner

\footnotetext{
${ }^{247}$ See Issacharoff \& Witt, supra note 15, at 1603 (reporting that by 1935, twenty-nine jurisdictions had enacted such laws).

${ }^{248} I d$. at 1603-04 (reporting that by 1935, twenty-nine jurisdictions had enacted such laws).

249 See Robinette, supra note 241 , at 554 \& n.87.

${ }^{250}$ Simon, supra note 232, at 555.

${ }^{251} \mathrm{Id}$. at 572; see also id. at 527 (noting that "[ $\left.\mathrm{t}\right]$ hose who were even a little bit careless ended up just as injured or dead as those grossly so").

252 See COLUMBIA REPORT, supra note 237; see also Simon, supra note 232, at 567-75.

${ }^{253}$ Robert E. Keeton \& Jeffrey O'Connell, Basic Protection for the Traffic Victim 125-40 (1965). See also Engstrom, supra note 234, at 318.
} 
purchase first-party coverage that would cover the economic expenses, including medical expenses and lost wages, suffered by drivers and passengers in an automobile involved in a collision, as well as those of any injured pedestrians. ${ }^{254}$ These economic losses were capped at relatively modest amounts, and there was no recovery for noneconomic losses. However, seriously injured victims of accidents, whose injuries either fell within articulated categories of more severe injuries or whose medical expenses exceeded statutorily-defined monetary thresholds, were able to sue in tort to recover noneconomic damages. ${ }^{255}$ A few states merely enacted "add-on" no-fault programs that provided victims with an alternative for seeking compensation for defined economic losses without restricting access to the court system. ${ }^{256}$

By 1976, more than two-dozen states had enacted some form of no-fault compensation systems. $^{257}$ However, no state has followed suit since 1976, and a number of states have repealed their mandatory no-fault plans. ${ }^{258}$ Proponents of no-fault legislation promised that nofault insurance would be less expensive than that in the negligence-based system, ${ }^{259}$ but that predication failed to materialize. ${ }^{260}$ A recent, comprehensive RAND analysis concludes that the primary cause of higher than anticipated no-fault premium rates is that reimbursed medical costs in no-fault states are higher than in traditional tort states. ${ }^{261}$ Further, insurers in no-fault states now are paying the same portion of victims' noneconomic losses as those in fault-based states, ${ }^{262}$ presumably because victims in no-fault states are able to file common-law actions for

\footnotetext{
${ }^{254}$ See Engstrom, supra note 234, at 320.

${ }^{255} \mathrm{Id}$. at $320-21$.

${ }^{256} I d$. at 321.

${ }^{257}$ Id. at 306.

${ }^{258} \mathrm{Id}$.

259 See ANDERSON ET AL., supra note 242, at 42-43.

${ }^{260} I d$. at $48-49,63$

${ }^{261} \mathrm{Id}$. at 131 (concluding that "[i]ndividuals in no-fault states claimed the use of more medical care than claimants in other states."). Among the factors contributing to this are that no-fault statutes with "dollar thresholds" that enable claimants exceeding designated dollar amounts of medical expenses to sue in common-law tort encourage overclaiming of such expenses, $i d$. at 100; no-fault insurance typically pays before first-party health insurance, unlike liability insurance, $i d$. at 119; and claimants in no-fault states are more likely to utilize additional types of medical care, particularly chiropractors and physical therapists, than those in fault-based states. Id. at $124,126$. ${ }^{262} I d$. at 117.
} 
noneconomic damages if their medical bills exceed a designated dollar threshold or fall within certain prescribed categories of injuries. Finally, the higher costs of no-fault insurance in part reflects its comparative advantages over traditional liability insurance: compensation of a larger proportion of those injured in automobile accidents, ${ }^{263}$ faster claims reimbursement, and greater consumer satisfaction. $^{264}$

Despite the prevailing trend away from formal automobile no-fault compensation systems, even in jurisdictions that nominally retain the traditional negligence-liability insurance system, the reality is that auto-claims processing functions much like a no-fault system. ${ }^{265}$ The routinization of auto claims results from the combination that the only funds available to pay a judgment in most cases is the automobile insurance policy, usually with fairly modest limits, and that such claims are handled by "repeat players" on both sides, insurance claims adjusters and plaintiffs' attorneys who specialize in such claims. ${ }^{266}$ Often, such claims are simply settled at the amount of the liability policy. ${ }^{267}$

Far more importantly for our purposes, fault plays a far less dominant role in the settlement process than would be expected if these negotiators were truly "bargaining in the shadow of the law"268 of the negligence regime. In his comprehensive study of the claims settlement process published in $1970,{ }^{269} \mathrm{H}$. Laurence Ross found that the negligence regime's

\footnotetext{
${ }^{263}$ See U.S. Department of Transportation, Compensating Auto Accident Victims: A Follow-Up Report on No-Fault Auto Insurance Experiences 3 (1985) (concluding that "[m]ore victims receive compensation under no-fault than under fault systems.").

${ }^{264}$ See ANDERSON ET AL., supra note 242, at 131.

${ }^{265}$ See Issacharoff \& Witt, supra note 15, at 1615 (observing that "[t]he striking feature is the similarity of the mature tort injury system in auto claims to the administrative system of workmen's compensation"). See also generally Robinette, supra note 241, at 550-62 (describing the routinization of the auto claims process).

${ }^{266}$ See Robinette, supra note 241, at 559 (noting that "[m] any ... automobile accidents now had repeat players on both sides").

${ }^{267}$ See JOHN C.P. GOLDBERG \& BENJAMIN C. ZIPURSKY, OXFORD INTRODUCTIONS TO U.S. LAW: TORTS 395-96 (2010).

${ }^{268}$ See Robert H. Mnookin \& Lewis Kornhauser, Bargaining in the Shadow of the Law: The Case of Divorce, 88 YALE L.J. 950, 968 (1979) (introducing this fundamental concept providing that the legal rights of each party help determine settlement outcomes).

${ }^{269}$ H. Laurence Ross, SetTled Out of Court: The Social Process of Insurance Claims AdJustments (1970).
} 
requirement that there be fault for liability was frequently not observed. ${ }^{270}$ In order to settle cases quickly and expeditiously, the negotiating partners' determination of liability focused largely on whether one or both parties violated traffic laws. ${ }^{271}$ However, Ross observed that in the "large majority of cases, ... a claimant who has provable economic losses will recover something." 272 In virtually all cases, according to Ross, the claimant recovers at least her or his medical expenses. ${ }^{273}$ The determination of damages is also routinized, usually as some multiple of "medical expenses," often "three-times medicals."274

In recent years, the routinization of automobile claims has resulted in "settlement mills," plaintiffs' firms that specialize in automobile claims and often dominate the local market for such services. ${ }^{275}$ Such firms market aggressively, do little or no vetting of claims when they accept their clients, and handle extremely high caseloads. ${ }^{276}$ Settlement mills often engage in mass settlements, packaging claims that are weaker on the merits with those that are stronger. ${ }^{277}$ As Engstrom reports, “even cases with serious liability issues are often amicably resolved. Insurers will offer something ... for nearly every claim." ${ }^{278}$

In short, in practice the processing of routine automobile claims more closely resembles the workers' compensation system than it does the traditional negligence model. Claimants who can prove medical expenses recover compensation, even if the case for liability is weak or nonexistent. Like workers' compensation, the amount of the settlement is often formulaic. Claims processing is swift, and what would happen at trial is of minor interest at best.

\footnotetext{
${ }^{270}$ See Robinette, supra note 241, at 556.

${ }^{271}$ See Ross, supra note 269, at 98; see also Robinette, supra note 241, at 556.

272 Ross, supra note 269 , at 81.

${ }^{273} I d$. at $51,202-03$.

${ }^{274}$ Id. at $107-08$.

275 See Nora Freeman Engstrom, Run-of-the-Mill Justice, 22 GEO. J. LEGAL ETHICS 1485, 1486, 1519 (2009).

${ }^{276}$ See Nora Freeman Engstrom, Sunlight and Settlement Mills, 86 N.Y.U. L. REV. 805, 816-17 (2011).

277 See Engstrom, Run-of-the-Mill Justice, supra note 275, at 1536 (reporting that "[1] egally strong and weak claims are lumped together.").

${ }^{278}$ Engstrom, Sunlight and Settlement Mills, supra note 276, at 828; see also Engstrom, Run-of-the-Mill Justice, supra note 275, at 1535 (describing "near universal (albeit sometimes partial) compensation.").
} 
Settlements are capped either by a formula such as "three times specials" or by the limits of the defendants' insurance policies.

\section{The Rise and Fall of Strict Products Liability}

The mass production of automobiles and other consumer products also led to changes in the law governing what injured consumers or users of products needed to prove to recover damages from product manufacturers for personal injuries.

\section{The End of the Privity Requirement}

At the turn of the twentieth-century, it was generally impossible for victims to successfully sue the distant manufacturers whom had replaced local craftsman as the producers of household items. ${ }^{279}$ Before the Industrial Revolution, Americans generally relied upon themselves, family members, and local craft and trade individuals to supply the goods that they used in daily life. ${ }^{280}$ That all changed in the early twentieth century with the development of mass production factories and extensive railroad networks. ${ }^{281}$ The manufacturer and the product consumer now rarely met one another. Instead, the manufacturer sold its finished products to a chain of one or more distributors who then sold their products to retailers who finally sold their products to consumers. Ultimately, the finished product played a role in injuring the consumer, another user of the product, or even a bystander. ${ }^{282}$

In the nineteenth century, the law had not caught up with these changes in the economy that resulted from technological change. Those injured by defective products were precluded from recovering from manufacturers because English and American courts had consistently held

\footnotetext{
${ }^{279}$ See infra notes 281, 292, and accompanying text.

${ }^{280}$ See supra notes 32, 208, and accompanying text.

${ }^{281}$ See, e.g., Escola v. Coca Cola Bottling Co., 150 P.2d 436, 443 (Cal. 1944) (Traynor, J., concurring) (observing that "[a]s handicrafts have been replaced by mass production with its great markets and transportation facilities, the close relationship between the producer and consumer of a product has been altered."); SUSAN STRASSER, SATISFACTION GUARANTEED: THE MAKING OF THE AMERICAN MASS MARKET 23 (2004) (stating that "[m]arketbuilding required systems that could move large quantities of raw materials, finished goods, energy, and information over long distances.").

282 See DAVID G. OWEN, Products Liability LAW $\$ 5.33$ (3d ed. 2014).
} 
that the supplier of a product owed a duty of care only to those in "privity," that is, linked by a direct contractual relationship, with the manufacturer. ${ }^{283}$ In the seminal decision in MacPherson v. Buick Motor Co. ${ }^{284}$ Judge Cardozo held that an automobile manufacturer owed a duty of care to a user of a product "to make it carefully" whenever "it is reasonably certain to place life and limb in peril when negligently made." 285 In doing so, Cardozo explicitly acknowledged the technological impetus for this important change in the law: "Precedents drawn from the days of travel by stage coach do not fit the conditions of travel today." 286 He went on to stress the appropriateness of changing the law to "the needs of life in a developing civilization.",287

\section{The Emergence of "Strict" Products Liability}

A few decades later, between the early 1960s and the mid-1980s, the mass production, consumer society prompted the development of "strict products liability," which at the time appeared to be "the most radical and spectacular" change in American tort law during the twentieth century. ${ }^{288}$ At least facially at the time of its emergence, this new regime governing the liability of product manufacturers and other product sellers to the purchasers and users of their products, as well as bystanders injured by the products, did not require the plaintiff to prove fault or negligence. ${ }^{289}$ As such, strict products liability appeared to create an important commonlaw exception to the general requirement that the personal injury claimant prove that the defendant acted with fault. ${ }^{290}$

\footnotetext{
${ }^{283}$ See, e.g., Winterbottom v. Wright, 10 M. \& W. 109, 152 Eng. Rep. 402 (Ex. 1842) (denying recovery to the driver of a stagecoach against a contractor who had supplied the vehicle to the postmaster because there was no privity of contract between the parties).

284111 N.E. 1050, (N.Y. 1916).

285 Id. at 1053 .

${ }^{286} \mathrm{Id}$.

${ }^{287}$ Id. In the decades that followed, other states fell in line behind the MacPherson decision, making it one of the most important American tort opinions of all time. See, e.g., William L. Prosser, The Assault upon the Citadel (Strict Liability to the Consumer), 69 YALE L.J. 1099, 1100 (1960) (noting that the decision "swept the country"). ${ }^{288}$ Robert W. Miller, Significant New Concepts of Tort Liability-Strict Liability, 17 SYRACUSE L. REV. 25,29 (1965) (quoting American Law Institute Meeting, 32 U.S. L. WEEK 2623, 2627 (1964)).

289 See RESTATEMENT (SECOND) OF TORTS §402A (2)(a) (AM. LAW INST. 1965) (stating that the seller of a product will be held liable even if it "has exercised all possible care in the preparation and sale of [its] product").

290 The adoption of strict products liability during the period extending from the early 1960s through the mid-1980s was but one of several changes in tort doctrine during this period that made it easier for personal injury claimants to
} 
The causal connection between technological change in the economy and the emergence

of strict products liability was unambiguously described in the profound concurring opinion of a then-young California Supreme Court Justice, Roger Traynor, in Escola v. Coca-Cola Bottling Co. ${ }^{291}$ decided in 1941. Justice Traynor contended that a manufacturer should be held liable to an injured consumer even without proof of negligence, in part because of the difficulty the injured consumer typically experienced in proving that the manufacturer was negligent:

As handicrafts have been replaced by mass production with its great markets and transportation facilities, the close relationship between the producer and consumer of a product has been altered. Manufacturing processes ... are ordinarily either inaccessible to or beyond the ken of the general public. The consumer no longer has means or skill enough to investigate for himself the soundness of a product, $\ldots$ and his erstwhile vigilance has been lulled by the steady efforts of manufacturers to build up confidence by advertising ... . ${ }^{292}$

Traynor also wrote that the technologically induced changes in the economy meant that the manufacturer is in a better position to minimize losses by anticipating the risks posed by products and preventing repetitive injuries from such products. ${ }^{293}$ Finally, Justice Traynor recognized that the manufacturer is in a better position to spread the losses sustained by consumers: "The cost of an injury and the loss of time or health may be an overwhelming misfortune to the person injured, and a needless one, for the risk of injury can be insured by the manufacturer and distributed among the public as a cost of doing business." ${ }^{294}$ By the mid-

recover compensation, including notably the change from contributory negligence as a total bar to recovery to comparative fault and the total or partial abrogation of a number of common law immunities. See VIRGINIA E. NOLAN \& EDMUND URSIN, UNDERSTANDING ENTERPRISE LIABILITY 15 (1995) (noting that "enterprise liability scholars were appalled by the "harshness"” of doctrines such as "traditional landowner rules, the doctrines of charitable, governmental, and intrafamily immunity, and the defenses of assumption of the risk and contributory fault."); Gifford \& Jones, supra note 4, at 574-85 (2016) (identifying five doctrinal changes that occurred in many but not all jurisdictions during the late twentieth century as ones that enabled plaintiffs to more readily have their cases heard by juries). However, the adoption of strict products liability was unusual because it explicitly returned the standard of liability to what was labeled as strict liability.

291150 P.2d 436, 440 (Cal. 1944) (Traynor, J., concurring) (contending that "a manufacturer incurs an absolute liability when an article that he has placed on the market ... proves to have a defect that causes injury to human beings.").

292 Id. at 443.

${ }^{293} \mathrm{Id}$. at 443 (concluding that "[ $\left.\mathrm{t}\right]$ he consumer no longer has means or skill enough to investigate for himself the soundness of a product.").

${ }^{294}$ Id. at 441. 
1980s, virtually all American jurisdictions had adopted a strict liability standard in products cases. $^{295}$

\section{The Reversion to Fault-Based Standards in Products Liability}

In fact, there was less to the apparent change from a negligence standard to a strict liability standard in products liability cases that occurred between the early1960s and the mid1980s than met the eye. The early strict product liability cases were ones involving what is now known as a "manufacturing defect," that is, "when the product departs from its intended design."296 Schwartz argued, consistent with Justice Traynor's “difficulty of proving negligence" rationale for strict product liability in Escola, ${ }^{297}$ that there is a high correlation between manufacturing defects and negligence. ${ }^{298}$

Even if one accepts at face value the assertion that liability for manufacturing defects is decided under a "true strict liability" 299 standard that sometimes produces different results from those under a negligence standard, the fact remains that a majority of products litigation involves “design" and "warning" defects, not manufacturing defects. ${ }^{300}$ In other words, even when a product "conforms to the intended design," it might not be reasonably safe because "the intended design itself" or the lack of adequate instructions or warnings makes it unreasonably unsafe..$^{301}$

\footnotetext{
295 See 3 HARPER ET AL., supra note 141, $\$ 28.15$ n.7 (noting that at least 46 states have adopted strict products liability or its functional equivalent).

${ }^{296}$ ReStATEMENT (ThIRD) OF TORTS: Products Liability § 2(a) (AM. LAW Inst. 1998). See Richard L. Cupp Jr. \& Danielle Polage, The Rhetoric of Strict Products Liability Versus Negligence: An Empirical Analysis, 77 N.Y.U.L. REV. 874, 889 (2002) (stating that "[m]ost of the early cases applying strict liability in tort involved manufacturing defects rather than design defects or inadequate warnings.").

${ }^{297}$ See supra note 292 and accompanying text.

${ }^{298}$ See Gary T. Schwartz, The Beginning and Possible End of The Rise of Modern American Tort Law, 26 GA. L. REV. 601, 624 (1992) (arguing that strict liability does not "dramatically chang[e] ... the pattern of litigation results ... under a negligence standard").

${ }^{299}$ David Owen, Products Liability Law Restated, 49 S.C. L. REV. 273, 283-84 (1998) (noting that the standard of liability for manufacturing defects contained in the Restatement (Third) of Torts: Products Liability originates with contract law).

${ }^{300}$ See MARK A. GEISTFELD, PRINCIPLES OF ProduCtS LiABILITY 85 n.1 (2006) (finding that in a 1985 study of products liability claims over $\$ 100,000$, the majority were based on design defects).

${ }^{301}$ See ReSTATEMENT (ThIRD) OF TORTS: PRODUCTS LiABILITY §1, cmt. a (AM. LAW InST. 1998).
} 
In the early years of strict product liability, courts focused on manufacturing defects. ${ }^{302}$

In the comparatively infrequent number of cases in which the issue arose, courts typically addressed the issue of whether a design defect was present through the lens of the "consumer expectations test, ${ }^{303}$ that is, whether the product was "dangerous to an extent beyond that which would be contemplated by the ordinary consumer who purchases it." ${ }^{304}$ By the mid-1970s, however, courts began to move toward the "risk-utility" test for determining whether there is a design defect that provides that such a defect existed only if the costs of taking additional precautions is less than the "probability and seriousness of harm" that would be prevented. ${ }^{305}$ The risk-utility test, of course, is a version of the cost-benefit analysis or "Hand formula"306 that defines negligence. In short, the risk-utility test for design defects marks a return to a negligence

\footnotetext{
${ }^{302} I d$. (stating that "[i]mposition of liability for design defects ... was relatively infrequent until the late 1960s and early 1970s).

${ }^{303}$ See OwEN, supra note 282, § 5.6, at 292-99.

${ }^{304}$ RESTATEMENT (SECOND) OF TORTS §402A, cmt. i (AM. LAW INST. 1965); see also id. at cmt. g (stating that strict liability "applies only where the product is ... in a condition not contemplated by the ultimate consumer, which will be unreasonably dangerous to him."). The consumer expectations test, with its origins in the law of warranty, see OWEN, supra note 282, at 291, does not require negligence on the part of the manufacturer or other seller, and therefore can legitimately be classified as a form of strict liability. However, courts soon encountered a variety of problems in applying the consumer expectations test, notably the vagueness of the test, particularly when jurors applied it to technologically complex products. Id. at 29. See, e.g., Heaton v. Ford Motor Co., 435 P.2d 806, 809 (Or. 1967) (stating that a jury would have to speculate how a 5-to-6-inch rock would normally damage a truck traveling on a highway because "[h]igh-speed collisions with large rocks are not so common ... that the average person would know from personal experience what to expect under the circumstances.").

${ }^{305}$ Raney v. Honeywell, Inc., 540 F.2d 932, 935 (8th Cir. 1976). The risk-utility test involves "a balancing of the probability and seriousness of harm against the costs of taking precautions. Relevant factors to be considered include the availability of alternative designs, the cost and feasibility of adopting alternative designs and the frequency or infrequency of injury resulting from the design." Id. (citations omitted).

${ }^{306}$ See United States v. Carroll Towing Co., 159 F.2d 169, 173 (2d Cir. 1947) (Hand, L., J.) (describing the costbenefit test for negligence using algebraic terms); see also RESTATEMENT (THIRD) OF TORTS: LIABILITY FOR PHYSICAL AND EMOTIONAL HARM $§ 3$ (AM. LAW INST. 2010) (stating that "[p]rimary factors to consider in ascertaining whether the person's conduct lacks reasonable care are the foreseeable likelihood that the person's conduct will result in harm, the foreseeable severity of any harm that may ensue, and the burden of precautions to eliminate or reduce the risk of harm."); Posner, supra note 153, at 32-34 (endorsing "Learned Hand's famous formulation").
} 
standard. ${ }^{307}$ In 1998, the Restatement (Third) of Torts: Products Liability adopted a variant of

the risk-utility test for design defects, ${ }^{308}$ and today most courts follow the risk-utility approach. ${ }^{309}$

Similarly, the law governing warning defects also has largely returned to a negligence

standard. The Restatement (Third), for example, indicates that a warning defect exists only

"when the foreseeable risks of harm posed by the product could have been reduced or avoided by

the provision of reasonable instructions or warnings." 310 The Restatement reporters observed that

"[a]n overwhelming majority of jurisdictions supports the proposition that a manufacturer has a

duty to warn only of risks that were known or should have been known to a reasonable

person." 311 This same basic principle inheres in what became known as the "state-of-the-art"

defense, ${ }^{312}$ under which compliance with "the level of scientific and technological knowledge

existing at the time the product in question was designed for manufacture" is generally regarded

as either a total bar to liability or at least a factor that the jury could consider in deciding whether

a product was defective. ${ }^{313}$ The state of the art defense essentially turns strict liability for failure

to warn into negligence for failure to warn. In any event, courts and commentators usually agree

that today, liability in negligence for failure to warn and under a strict liability warning defect

\footnotetext{
${ }^{307}$ In the 1960s, John Wade and W. Page Keeton each independently argued that the distinction between negligence and strict product liability should be that under strict liability, knowledge of a product risk, even if it were not reasonably foreseeable, should be imputed to the manufacturer. See W. Page Keeton, Products Liability-

Inadequacy of Information, 48 TEX. L. REV. 398, 404 (1970); John W. Wade, Strict Tort Liability of Manufacturers, 19 Sw. L.J. 5, 15 (1965); see also Cepeda v. Cumberland Eng'r Co., 386 A.2d 816, 826-27 (N.J. 1978) (adopting principle). Over the longer term, however, this view has rarely prevailed. See infra notes 312-316 and accompanying text.

${ }^{308}$ RESTATEMENT (THIRD) OF TORTS: PRODUCTS LiABILITY § 2(b) (AM. LAW INST. 1998) (adopting standard of riskutility analysis with a requirement of an available "reasonable alternative design" that would make the product safer).

${ }^{309}$ See OWEN, supra note 282, at 299 (reporting that (reporting that "most courts ... use some form of 'risk-utility' ... test).

${ }^{310}$ Restatement (THIRD) OF TORTS: PRODUCTS LiabiLITY § 2(c).

${ }^{311} \mathrm{Id}$. at $\mathrm{cmt}$. $\mathrm{m}$. (citing leading cases).

312 True strict liability in warning cases would mean that manufacturers could be held liable if they failed to warn of a risk of which they neither were aware nor reasonably should have been aware. See, e.g., Beshada v. JohnsManville Prods. Corp., 447 A.2d 539, 546-47 (N.J. 1982) (holding manufacturer liable for failure to warn of unknowable risks because of the risk-distribution goal of strict product liability). However, decisions imposing this type of strict liability in warning cases usually did not last long. See e.g., Feldman v. Lederle Labs., 479 A.2d 374, 386 (N.J. 1984) (stating that pharmaceutical manufacturer's "conduct should be measured by knowledge at the time the manufacturer distributed the product.").

${ }^{313}$ Potter v. Chicago Pneumatic Tool Co., 694 A.2d 1319, 1346-47 (Conn. 1997) (discussing application of state of the art in warning and defect cases).
} 
claim are essentially coterminous. ${ }^{314}$ Additionally, in design defect cases, the requirement that the plaintiff prove the availability of a reasonable alternative design ${ }^{315}$ in effect brings state of the art back into the equation as a complete defense: the Restatement defines "reasonable" in this context to mean "technologically feasible and practical."316

By the mid-1980s, the reaction against "strict" products liability spread from the judicial arena to state and federal legislative halls. ${ }^{317}$ Legislators perceived, accurately or not, that strict products liability imperiled the activities of product manufacturers and distributors that they deemed to possess great social utility. ${ }^{318}$ The less common variety of tort reform statutes restricted the circumstances in which victims were able to recover from defendants, ${ }^{319}$ while more widespread statutory reforms limited the amount of damages that a successful claimant could recover from a manufacturer. ${ }^{320}$

\section{Assessing the Product Liability "Revolution"}

In and of itself, the early twentieth-century decision in MacPherson ${ }^{321}$ marked a dramatic change in the American law governing personal injuries by expanding the duty of care owed by

\footnotetext{
${ }^{314}$ See, e.g., Anderson v. Owens-Corning Fiberglas Corp., 810 P.2d 549, 561 (Cal. 1991) (Mosk, J., concurring and dissenting) (stating that "[i]n no area of strict products liability has the impact of ... negligence become more pronounced than in failure-to-warn cases."); Gourdine v. Crews, 955 A.2d 769, 782 (Md. 2008) (observing that "negligence concepts and those of strict liability have 'morphed together' ... in failure to warn cases.").

315 ReSTATEMENT (THIRD) OF TORTS: PRODUCTS LIABILITY § 2(b) (AM. LAW INST. 1998).

${ }^{316} \mathrm{Id}$. at cmt. f.

${ }^{317}$ See Joanna M. Shepherd, Products Liability and Economic Activity: An Empirical Analysis of Tort Reform's Impact on Businesses, Employment, and Production, 66 VAND. L. REV. 257, 258-59 (2013) (reporting that tort reform advocates "have won numerous victories as legislatures continue to enact reforms that reduce the scope of products liability.").

${ }^{318}$ E.g., National Childhood Vaccine-Injury Compensation Act: Hearing on S. 2117 Before the S. Comm. on Labor and Human Resources, 98th Cong. 49, at 4 (1984) (statement of Sen. Edward Kennedy) (arguing that "[w]e must be able to get vaccines to children ... at an acceptable cost and without creating exorbitant and unpredictable legal difficulties. ... We cannot tolerate a system which discourages immunization").

${ }^{319}$ E.g., DEL. CODE ANN. tit. 18, § 7001 (2016) (providing a "sealed container defense" for product sellers); IDAHO CODE § 6-1403 (2016) (permitting recovery only during the "useful safe life" of the product, usually ten years); WASH. REV. CODE ANN. § 7.72.010 (LexisNexis 2016) (barring products liability for sellers of used products). ${ }^{320}$ E.g., FLA. StaT. ANN. § 768.76 (LexisNexis 2013) (mandating that courts deduct the amount of compensation received from collateral sources in some circumstances); MD. CODE ANN., CTS. \& JUD. PROC. § 11-108 (LexisNexis 2013) (capping noneconomic damages in personal injury cases at $\$ 500,000$ in 1994 with a $\$ 15,000$ annual incremental increase thereafter); OR. REV. STAT. ANN. $\$ 30.925$ (West 2013) (prohibiting punitive damages in products liability cases).

${ }^{321}$ MacPherson v. Buick Motor Co., 111 N.E. 1050 (N.Y. 1916).
} 
manufacturers and other possible defendants to all foreseeable victims of their negligence.

Additionally, in the 1960s and the 1970s, most courts replaced the heretofore dominant

negligence regime with a standard of strict liability for product liability cases, at least in cases

involving manufacturing defects, the type of product defects that had almost exclusively

dominated claims until that point. These two changes, marking significant modification of the

preexisting negligence regime, resulted largely from the difficulty of proving liability in a

products cases under the ex-ante negligence standard. In the early years of strict products

liability, there can be little doubt that these changes increased the frequency of product liability

claims, even if the issue of whether this growth in claims continued into the 1980s is strongly

contested. ${ }^{322}$

The subsequent extension of true strict liability to design and warning defects met with

far less success and sparked a substantial reversion to the preexisting negligence regime. The

more restrictive court decisions and legislative enactments beginning in the 1980s reflected the arguments of manufacturers and their insurers that the increases in the aggregate liability they

faced as a result of strict product liability stifled economic activity, drove companies out of

business, and prevented products from coming to the market. ${ }^{323}$ As was the case a century

earlier when courts cut back on the liability exposure of railroads and other industries,

legislatures, in particular, acted on the belief that the social utility of these defendants' activities

justified decreasing their liability exposure. The net result, at least for liability exposure

\footnotetext{
322 Compare Theodore Eisenberg \& James A. Henderson, Jr., Inside the Quiet Revolution in Products Liability, 39 UCLA L. REV. 731, 748-49 (1992) (observing a decline in both the number of product liability claims filed and plaintiff success rates in the 1980s), with Shepherd, supra note 317, at 266-67 (reporting an increase in products liability cases commenced in federal court from 2,393 in 1975 to 14,145 in 1987, and further stipulating that "this number drastically underestimates the true number of products liability claims because many tort claims are brought in state courts").

${ }^{323}$ See, e.g., Product Liability Reform, AM. TORT REFORM Ass'N, http://www.atra.org/ issue/product-liability/ (last visited Sept. 17, 2017); Torts of the Future, U.S. CHAMBER: INST. FOR LEGAL REFORM (Mar. 29, 2017), http://www.instituteforlegalreform.com/research/torts-of-the-future; Legal Policy \& Product Safety, NAT'L Ass'N OF MFRS., http://www.nam.org/Issues/Legal-Policy-and-Product-Safety/ (last visited Sept. 17, 2017).
} 
resulting from design and warning defects, is that for the most part, the so-called "products liability revolution" now appears to have been largely a faux revolution.

\section{The Association between Technological Progress and Changes in the Law of Personal Injury Compensation}

The substantial changes in tort doctrine described in this Article indicate an association between technological and doctrinal change. New waves of technology and the changes in the economy that come with them result in varying (1) frequencies of personal injuries, (2) severities of such injuries, (3) degrees of difficulty in proving claims for compensation, and (4) magnitudes of social utility. Analysis of these factors determines whether the ex-ante rules governing liability for personal injuries are likely to change and, specifically, whether the new doctrinal structure governing liability will be based on common-law fault (negligence), common-law strict liability, or a legislatively-mandated no fault compensation system that limits damages recoverable by claimants.

The first factor is the frequency of personal injuries resulting from the widespread adoption of a new wave of technologies. For example, the technological changes of the midand-late nineteenth century likely increased the frequency of personal injuries and certainly increased the frequency of nontrivial injuries leading to legal claims. ${ }^{324}$ As the complexity of the machinery causing injury increased, the result was a greater likelihood that the operation of the machinery would malfunction. Moreover, because accidents involving machinery were much more likely than those during the preindustrial era to result in severe injuries, a higher percentage of injured victims filed claims.

The second factor, the severity of the resulting injuries, is an even more important determinant of doctrinal change. As the level of technology continually advanced from the first

\footnotetext{
${ }^{324}$ See supra note 192 and accompanying text.
} 
half of the nineteenth century through the first half of the twentieth century, injuries became more severe. ${ }^{325}$ Locomotives, automobiles, and industrial machinery were more likely to result in crippling or even fatal injuries than were horses that threw a rider or the carelessness of coworkers using hand-tools.

The third technologically-inspired factor impacting the tort liability standard is the difficulty that victims experience in proving claims against the tortfeasors whose conduct caused the injuries. For example, it was more difficult for a worker employed in a massive factory or working for a railroad to prove both causation and fault than it was for a victim injured by a coworker in an early nineteenth-century craft shop. Similarly, it is even more difficult to establish causation and fault in a products liability case when the harm was caused by a product manufactured at a factory distant in location, and possibly distant in time as well.

The product of the frequency of additional paid claims resulting from a new set of technological changes times the mean severity of these paid claims yields the amount of the societal increase in the aggregate liability exposure of tortfeasors. The frequency of paid claims is affected not only by the frequency of personal injuries, but also by the difficulty of proving the claim. The greater the difficulty, the less the liability exposure of tortfeasors.

The fourth and final variable affecting tort liability is the change in social utility resulting from each new wave of technological innovation. To the extent that courts and legislatures perceive that new technologies offer great social utility, they are less likely to either impose strict liability or require the tortfeasor to fully compensate the victim for all damages.

Obviously, the first, second, and fourth factors echo the variables incorporated in Judge Learned Hand's quasi-algebraic formula for determining whether any particular defendant's or plaintiff's conduct was negligent, but apply these same variables to the aggregate changes in the economy caused by a new set of technological and technologically-inspired economic

\footnotetext{
${ }^{325}$ See supra notes $82-87,91-92$, and accompanying text.
} 
changes. ${ }^{326}$ The third factor, the difficulty of proving liability in the face of new technological developments, is suggested by Justice Traynor's concurring opinion in Escola v. Coca Cola Bottling Co. ${ }^{327}$

It is not clear in the abstract which direction any increase in either of the first two factors, the frequency or severity of personal injuries, pushes the liability standard. On one hand, an increase in the frequency of personal injuries is likely to lead to demands to ease the ability of victims to recover compensation. For example, the increased number of injuries among workers resulting from the proliferation of railroads and factories led to the enactment of workers' compensation. ${ }^{328}$ On the other hand, a greater frequency of personal injury claims also increases the aggregate liability exposure of tortfeasors engaged in productive activities benefiting society. This factor, pointing toward the tightening the requirements for liability, proved decisive when the negligence regime replaced the ex-ante strict liability standard after the Industrial Revolution. ${ }^{329}$

Similarly, an increase in the severity of the resulting injuries points in two different directions regarding a change in liability standard. Society and its judges perceive victims with more severe injuries, such as the smashing of bones following the Industrial Revolution, as more in need of compensation than those that suffered less serious injuries resulting from older technologies. Again, however, an increased severity of injuries likewise magnifies the liability exposure of those perceived to be engaged in productive activities.

\footnotetext{
${ }^{326}$ See United States v. Carroll Towing Co., 159 F.2d 169, 173 (2d Cir. 1947) (suggesting that "if the probability be called P; the injury, L; and the burden, B; liability depends upon whether B is less than L multiplied by P; i.e., whether B[is] less than PL.”); see also RESTATEMENT (THIRD) OF TORTS: LIABILITY FOR PHYSICAL AND EMOTIONAL HARM $\$ 3$ (2010) (providing that the “primary factors to consider in ascertaining whether the person's conduct lacks reasonable care are the foreseeable likelihood that the person's conduct will result in harm, the foreseeable severity of any harm that may ensued, and the burden of precautions to eliminate or reduce the risk of harm.").

327 See supra note 292 and accompanying text.

${ }^{328}$ See supra note 226 and accompanying text.

${ }^{329}$ See supra notes 196-202, and accompanying text.
} 
Any increase in the difficulty of proving the ex-ante requirements of liability resulting from new technologies points in favor of lessening the difficulties of proof. Thus, this factor typically points toward the adoption of either a common-law strict liability or no-fault compensation system, in either event abrogating the plaintiff's need to prove fault on the part of the tortfeasor. The choice between the two is likely determined by the synergistic effect between the difficulty-of-proof and severity-of-claims factors. With larger claims, such as cases involving product-liability manufacturing defects, the difficulty in proving the claim may point toward common-law strict liability. However, in claims where the ratio of the difficulty of proving the claim is high compared to the severity of the claim, difficulty of proof points toward a no-fault compensation system. This factor helps explain why social reformers and advocates for workers generally favored the adoption of workers' compensation, which eliminated the need for the victim to prove that the employer both caused the accident and acted with fault. ${ }^{330}$

The whole point of new technologies is to increase social utility, so the social utility factor generally points toward tightening the liability standards, that is, maintaining or strengthening the requirements for proof of fault.

Each successive wave of society-wide technological change in American history ruptured the fabric of the preexisting liability system. The mid-nineteenth century technological changes spawned by the Industrial Revolution, most notably the development of railroads, appear to have resulted in (1) an increased frequency of injuries that victims deemed worthy of attempts to seek compensation, (2) a significant increase in the severity of the harms, (3) an increased difficulty for victims proving their claims, and (4) the perception that the locomotives and other new industrial machinery greatly contributed to social utility. By themselves, the first three factors

\footnotetext{
${ }^{330}$ See WITT, supra note 32, at 170 (stating that the workers' compensation system "sought to make employers liable even in those cases in which conventional ways of thinking about causation in law would have assigned causal responsibility elsewhere.").
} 
might have led to a societal consensus that the rules governing liability should be loosened to more readily enable recovery. However, courts, buttressed by the contemporary consensus that technology was the key to progress, ${ }^{331}$ acted in a way suggesting they found that the social utility of new technologies outweighed the need to compensate the increased number of victims suffering substantially more severe injuries than in the preindustrial era. The weighing of the four factors is inherently a political choice, and here Horwitz and Friedman are correct in focusing on the shift in distributional consequences (from industrial tortfeasors to workers and other victims) resulting from the change from a strict liability standard to a negligence regime. ${ }^{332}$

A few decades later, legislatures reevaluated these same four factors following the development of the factory system and the proliferation of railroads and industrial machinery. ${ }^{333}$ In this instance, the (1) increased frequency of personal injuries resulting from these changes in the economic system brought about by new technologies and (2) the difficulty of proving that the employer acted with negligence, both pointed toward loosening the requirements for liability and adopting a no-fault or strict liability system.

It might have been expected that employers would vigorously oppose the adoption of a no-fault workers' compensation system. However, many employers promoted the adoption of workers' compensation because of their fear that the fellow-servant rule, a key component of the classical negligence regime, ${ }^{334}$ was about to collapse. If that had happened, employers' liability exposure within the common-law system, with the concomitant power of juries to award full damages including difficult-to-control noneconomic damages, ${ }^{335}$ would have increased dramatically. These employers convinced legislators of the need to limit the anticipated increase

\footnotetext{
${ }^{331}$ See supra notes 70-73, and accompanying text.

332 See supra notes 156-159, and accompanying text.

${ }^{333}$ See supra notes 210-213, and accompanying text.

${ }^{334}$ See supra note 215 and accompanying text.

335 See, e.g., Seffert v. Los Angeles Transit Lines, 364 P.2d 337, 345-46 (Cal. 1961) (Traynor, J., dissenting) (discussing "arbitrary" nature of jury awards for pain and suffering); Geressy v. Digital Equip. Corp., 980 F. Supp. 640, 656-57 (E.D.N.Y. 1997) (Weinstein, J.) (describing the "variability" of jury awards).
} 
in their aggregate liability exposure so as to not threaten the social utility of their enterprises. ${ }^{336}$ The way to do this was to limit the severity of claims paid through the workers' compensation system, making the aggregate liability exposure more predictable and less than what employers feared would happen if the fellow-servant rule was abolished.

Much like railroads and factories, the development of automobiles affected a change in tort liability. Their widespread use led to an onslaught of accidents and a dramatic increase in the frequency of injuries. Coupled with laws mandating requiring insurance coverage, the result was a dramatic increase in the frequency of claims. The severity of these resulting claims varied widely, but even with larger claims, the amount paid was almost always limited by insurance policy limits. As a result, the severity of paid claims was modest. The difficulty of proving negligence in any given case varied widely, but tended to be substantial when compared with the amount of the expected recovery. This reality, combined with the high frequency of claims, led to the adoption of formal no-fault plans in a minority of states. In most jurisdictions, however, the negligence regime formally remained intact, but in fact insurance claims adjusters and specialized plaintiffs' attorneys routinized the settlement process, deemphasized the role of fault, and assessed damages in a formulaic manner, all of which resemble a no-fault compensation system more than they do the traditional tort litigation system.

Tracing how changes in liability standards for product manufacturers and suppliers resulted from the development of the mass production/mass consumption society is more difficult, because the changes took place in different decades, pointed in opposite directions, and indeed were adopted by different branches of government. The mass production society increased both the frequency and severity of personal injuries, but most importantly, also increased the difficulty of a victim proving that the manufacturer or other distributor caused the

\footnotetext{
${ }^{336}$ See supra note 221 and accompanying text.
} 
harm and was at fault. ${ }^{337}$ Until the legislative and judicial backlash that began in the 1970s, the difficulty-of-proof factor was the deciding factor in judicial opinions and resulted in significant changes in the law from the negligence regime toward a strict-liability standard, including both the abrogation of the privity limitation ${ }^{338}$ and the abolition of the need to prove the manufacturer's fault in cases involving manufacturing defects. ${ }^{339}$ By the 1980 s, however, courts and especially legislatures became persuaded that the increased liability exposure of product manufacturers and distributors threatened their ongoing activities, which were perceived to be of great social utility. Most courts functionally returned to a negligence-standard to govern design defect and warning defect cases, and legislatures imposed a variety of limitations on the liability exposure of product sellers including ones affecting either the frequency of successful claims ${ }^{340}$ or the severity of such claims. ${ }^{341}$

\section{The Second American Technological Revolution-Autonomous Vehicles, Robots, and Artificial Intelligence—and the Future of Liability Law}

American society is in the midst of the second great technological revolution, one characterized by autonomous vehicles, robots, networked medical devices, and artificial intelligence. The Industrial Revolution replaced humans and animals as suppliers of physical force with machines. ${ }^{342}$ In the new technological revolution, the contemporaneous decisionmaking that directs the physical force that is capable of inflicting personal injury is transferred from human beings to machines. ${ }^{343}$

\footnotetext{
337 See supra note 292 and accompanying text.

338 See supra notes 283-287, and accompanying text.

339 See supra notes 296-298, and accompanying text.

${ }^{340}$ See supra note 319 and accompanying text; see also Shepherd, supra note 283, at 269-71 (describing the legislative "attack on products liability law" during the 1980s).

341 See supra note 320.

342 See supra notes 27-30, 78-81, and accompanying texts.

343 See David C. Vladeck, Machines Without Principals: Liability Rules and Artificial Intelligence, 89 WASH. L. REV. 117,120 (2014) ("[T]he machine functions and makes decisions in ways that can be traced directly back to the design, programming, and knowledge humans embedded in the machine."); see also Bryant Walker Smith, Automated Driving and Product Liability, 2017 MiCH. ST. L. REV. 1, 47 (2017) (using a minor crash between a Google autonomous car and a bus to illustrate the same point). However, Ryan Calo notes that "[r]obotics increasingly display emergent behavior, meaning behavior that ... cannot be anticipated in advance by operators." RYAN CALO, CENTER FOR
} 
Robots and other machines where human-decision making is, at a minimum, removed in time from the operation of the machines, already cause deaths and injuries. ${ }^{344}$ For example, according to the Occupational Safety and Health Administration, robots caused at least thirtyeight American workplace deaths and injuries between 1984 and 2014. ${ }^{345}$ Both industrial and surgical robots have caused injuries resulting in personal injury lawsuits against their manufacturers. ${ }^{346}$ Autonomous vehicles, however, pose the greatest challenge to preexisting tort law in the twenty-first century. For this reason, I focus here on autonomous vehicles and the coming revolution in tort law that will result.

Autonomous vehicle technologies enable the vehicle itself to make the decisions necessary for safe operation. ${ }^{347}$ Vehicles already on the market today include such automated features as lane-departure warnings, cruise control that senses the presence of other vehicles and adjusts accordingly, crash warning features, and automated parking technology. ${ }^{348}$ Fully autonomous vehicles, currently under development and expected to be available to consumers on a widespread basis by $2021^{349}$ will enable the driver to "cede full control of all safety-critical

TECHNOLOGy InNOVATION AT BROOKINGS, THE CASE FOR A FEDERAL RoBotics COMMISSION 5 (2014), https://www.brookings.edu/wp-content/uploads/2014/09/RoboticsCommissionR2_Calo.pdf. See also Calo, Robots in American Law 40 (Univ. of Wash. Sch. of Law Research Paper No. 2016-04, 2016),

https://papers.ssrn.com/sol3/papers.cfm?abstract_id=2737598 (describing "emergence" as the ability of robots "that do not need to be programmed to solve tasks, at least not in the same way as an entirely bounded system[,]" but instead can "behave in complex, unanticipated ways.").

${ }^{344}$ See Balkin, supra note 1, at 46 ("Robots will ... break people's limbs"); Calo, supra note 2, at 515, 534 (describing robotics as "the next transformative technology" that acts on the world physically and possesses "the capacity to do physical harm").

${ }^{345}$ See Accident Search Results: "Robot", OCCUPATIONAL SAFETY AND HEALTH ADMINISTRATION https://www.osha.gov/pls/imis/AccidentSearch.search?acc_keyword=\%22Robot\%22\&keyword_list=on (last visited Sept. 22, 2017) (listing accidents involving robots).

${ }^{346}$ See e.g., Payne v. ABB Flexible Automation, No. 96-2248, 1997 U.S. App. LEXIS 13571 (8th Cir. June 9, 1997) (alleging negligence and strict liability against manufacturer of industrial robot that killed the robot operator and programmer); In re Intuitive Surgical, Inc., 883 F. Supp. 2d 1339, 1339 (J.P.M.L. 2012) (evaluating the merits of class action certification for "personal injuries arising out of alleged defects in the da Vinci Robotic Surgical System."); Taylor v. Intuitive Surgical, Inc., 389 P.3d 517, 530 (Wash. 2017) (holding manufacturer of robotic medical device liable for severe injuries and eventual death of patient inflicted by the device following a prostatectomy).

${ }^{347}$ See NidHi Kalra et AL., Liability and Regulation of Autonomous Vehicle TeChNOLOGIES 1 (RAND 2009), http://www.dot.ca.gov/newtech/researchreports/reports/2009/prr-2009-

28_liability_reg_\&_auto_vehicle_final_report_2009.pdf.

${ }^{348} I d$.

${ }^{349}$ See Neal E. Boudette \& John Markoff, The Fully Self-Driving Car Is Still Years Away, N.Y. TiMES (July 1, 2016), https://www.nytimes.com/2016/07/02/business/international/bmw-tesla-self-driving-car-mobileye-intel.html 
functions under certain traffic or environmental conditions" 350 or even "for an entire trip." 351

These vehicles use GPS-tracking and Lidar (laser-based sensing devices) to detect stationary and other moving objects in all directions. ${ }^{352}$ In addition, major car manufacturers are developing vehicle-to-vehicle and vehicle-to-infrastructure technologies that will, for example, enable autonomous vehicles to communicate with one another. ${ }^{353}$

If everyone owned and operated an autonomous vehicle, the frequency of personal injuries resulting from auto accidents would be very substantially reduced, probably by ninety percent or more. ${ }^{354}$ In the decades before such full-market penetration, the reduction in the frequency of personal injury accidents, while still substantial, will be much less. ${ }^{355}$ In contrast, the severity of injuries resulting from accidents involving autonomous vehicles is likely to be much greater than those currently caused by automobiles, because the autonomous vehicles are projected to be traveling at much greater speeds and in closer proximity to one another. ${ }^{356}$ Even

(reporting that BMW projects their fully autonomous cars to be available by 2021); Edward Taylor \& Paul Lienert, Autonomous Cars Race Narrows on Doubts About Clear Path to Profit, REUTERS (Aug. 8, 2017), https://www.reuters.com/article/us-autos-autonomous-bmw-idUSKBN1AO0Y7 (reporting that Intel projects a similar timeframe).

${ }^{350}$ In its 2013 "Preliminary Statement of Policy Concerning Automated Vehicles," the National Highway Transportation Safety Administration ("NHTSA") established five levels of automation for vehicles. NATIONAL HighWAY TRAFFiC SAFETy AdMIN., PRELIMINARY StATEMENT OF POLICY CONCERNING AUTOMATED VEHICLES 5, https://www.nhtsa.gov/staticfiles/rulemaking/pdf/Automated_Vehicles_Policy.pdf. The language quoted here is from what NHTSA classifies as a "Level 3" vehicle. Id. at 5.

${ }^{351}$ Id. (quoting NHTSA's criteria for a "Level 4" vehicle). See also Daniel A. Crane et al., A Survey of Legal Issues Arising from The Deployment of Autonomous and Connected Vehicles, 23 MiCH. TELECOMM. \& TECH. L. REV. 191, 202 (2017) (defining an "“autonomous vehicle' ... [as] a vehicle equipped with NHTSA level 3 or 4 technology.”).

352 Crane et al., supra note 351 , at 198.

${ }^{353} I d$. at $205-06$.

${ }^{354}$ See, e.g., The Internet of Cars: Joint Hearing Before the H Comm. on Oversight and Gov't Reform Subcomm. on Info. Tech. and Subcomm. on Transp. and Pub. Assets, 114th Cong. (2015), https://oversight.house.gov/wpcontent/uploads/2015/11/11-18-2015-Joint-Subcommittee-Hearing-on-Internet-of-Cars-Garfield-ITI-Testimony.pdf (prepared statement of Dean C. Garfield, President and CEO of the Information Technology Industry Council) (projecting that "automated vehicles can prevent up to 90 percent" of all automobile accidents); see also Neal Katyal, Disruptive Technologies and the Law, 102 GEO. L.J. 1685, 1688 (2014) (reporting that "researchers predict fatality rates could ultimately fall to $1 \%$ of current rates").

355 See Crane et al., supra note 351, at 301 (noting that "[i]t does no good if one's vehicle is fully autonomous if a vehicle in close proximity is driven by a reckless ... driver."); $f f$., Smith, supra note 343, at 6 (criticizing, implicitly, NHTSA's "analysis of the safety benefits of vehicle-to-vehicle communication ... [for] assum[ing] universal adoption"). But cf. Katyal, supra note 354, at 1688 (observing that "[e]ven if autonomous vehicles constituted only $10 \%$ of total cars on the road, it would save 1,100 lives per year.").

356 See KALRA ET AL., supra note 347, at 21 (conjecturing "that autonomous vehicle technologies are remarkably effective at virtually eliminating minor crashes caused by human error ... but ... that the comparatively few crashes that do occur usually result in very serious injuries or fatalities"). But see Smith, supra note 343, at 19 (suggesting that autonomous vehicles "may crash ... less severely"). If the severity of the losses inflicted by autonomous 
if the mean severity of claims increases, however, the aggregate cost of personal injuries

resulting from accidents involving autonomous vehicles is expected to be considerably less than the current costs of automobile accidents because of the sizable decrease in the frequency of accidents. $^{357}$

The substitution of autonomous vehicles for current automobiles and trucks will dramatically shift the distribution of which parties are legally liable for personal injuries resulting from accidents and hence which parties will pay for such liability, presumably through higher insurance premiums. Automobile drivers and owners, and their insurers, currently pay the bulk of the costs of personal injuries resulting from accidents. ${ }^{358}$ Drivers are in control of their vehicles, and injured parties must prove that they were negligent to recover. ${ }^{359}$ In contrast, with autonomous vehicles, the driver is not in control and cannot be held liable for negligence, except perhaps for unreasonably deciding to take control of a partially autonomous vehicle ${ }^{360}$ or for unreasonably failing to maintain an autonomous vehicle. Instead, the bulk of the liability will fall on the manufacturers of autonomous vehicles colliding with one another ${ }^{361}$ or the parties responsible for maintaining and mapping the surrounding infrastructure for autonomous vehicles, including assuring the presence of clear lane markings, uniform road markings and signs, and the

vehicles is greater than those currently resulting from automobile accidents, loss distribution considerations suggest either a liability regime that does not require proof of fault or first-party insurance with higher limits than current automobile policies. See generally Guido Calabresi, Some Thoughts on Risk Distribution and the Law of Torts, 70 YALE L.J. 499, 517 (1961) (noting that "taking a large sum of money from one person is more likely to result in economic dislocation ... than taking a series of small sums from many people").

${ }^{357}$ See KALRA ET AL., supra note 347, at 19, 34 (anticipating lower insurance costs).

${ }^{358}$ See Crane et al., supra note 351, at 20 (stating that at the present time, "we commonly speak of crashes as being caused by one or more at-fault drivers.").

${ }^{359}$ See KALRA ET AL., supra note 347, at 20 (noting that "[c]urrently, ... we ascribe blame to one or more drivers rather than to design features of the car."). When the harm resulting from automobile accidents is minor and falls within statutorily defined categories, no-fault liability applies in a minority of jurisdictions. See ANDERSON ET AL., supra note 242 , at 35 (describing coverage of a variety of no-fault plans).

${ }^{360}$ The driver is able to assume control of what NHTSA defines as a Level 3 autonomous vehicle. See supra note 350 and accompanying text.

${ }^{361}$ See Crane et al., supra note 351, at 256 (predicting that the proliferation of autonomous vehicles will result in a decrease in pricing of traditional automobile insurance and an increase in manufacturers' product liability premiums); KALRA ET AL., supra note 347, at 34 (concluding that "manufacturer liability is expected to increase"); Smith, supra note 343, at 53 (noting that automobile manufacturers "are likely to be liable for a much greater share of the costs of crashes involving automated driving systems"). 
external hardware and software necessary for vehicle-to-vehicle communications. ${ }^{362}$ States and localities and their contractors will be responsible for this infrastructure. ${ }^{363}$

It will probably be much more difficult for the plaintiff injured in an accident involving autonomous vehicles than it is for today's victim of an automobile accident to prove which party or parties "caused the accident" and whether they were at fault. ${ }^{364}$ The evidence likely will consist of "lines of code" rather than "broken mechanical parts"365 and require expert testimony. Additionally, unless the law changes, the injured victim will need to prove that a particular defendant engaged in tortious conduct that was a factual cause of the injury. ${ }^{366}$ Proving factual causation is usually fairly easy in today's routine automobile accident, but once autonomousvehicle-to-autonomous-vehicle accidents become the norm, investigators and jurors will be required to disentangle the electronic impulses from two or more vehicles, the response or lack of response from the infrastructure coordinating communications among vehicles, and perhaps the acts or omissions of drivers who took control of their vehicles unwisely or who failed to do so, in order to establish which parties were factual causes of the accident. ${ }^{367}$ If there is a significant possibility that one of the vehicles malfunctioned, the manufacturers of component parts, including software designers, join those whose actions or omissions may have contributed to the accident.

\footnotetext{
362 See Crane et al., supra note 351, at 306-09 (describing infrastructure changes necessary for autonomous vehicles including - the external Security Credential Management System ('SCMS') necessary to operate vehicle-to-vehicle communications and the resulting liability exposure of governments; suggesting also that localities may contract with private partners to undertake these tasks).

${ }^{363} I d$.

${ }^{364}$ See Vladeck, supra note 343, at 145 (concluding that "the complexity and sophistication of driver-less cars, and the complications that will come with the fact patterns that are likely to arise, are going to make proof of wrongdoing in any individual case extremely difficult.").

365 See Crane et al., supra note 350, at 256.

${ }^{366}$ In carefully circumscribed circumstances, the plaintiff is relieved of the burden of proving that a particular tortfeasor was a factual cause of the plaintiff's injury. See Donald G. Gifford, The Challenge to the Individual Causation Requirement in Mass Products Torts, 62 WASH. \& LEE L. REV. 873, 900-15 (2005).

${ }^{367}$ See Ujjayini Bose, Note, The Black Box Solution to Autonomous Liability, 92 WASH. U. L. REV. 1325, 1335, 1338 (2015) (noting that "it may be difficult to separate autonomous system malfunctions from driver negligence"; further noting that the driver may be liable for maintenance of the vehicle and for failing to take over the driving, or doing so unreasonably, in emergency situations).
} 
Determining which parties' conduct may have been factual causes of the accident only brings the victim of an accident part way to the goal of proving liability, which also requires proof of facts establishing tortious conduct. Here, the liability of drivers ${ }^{368}$ and, under current law, software engineers, ${ }^{369}$ will both require proof of negligence. The manufacturers of the autonomous vehicles and their component parts (excluding software) might be held liable on a strict liability basis, but even there, most jurisdictions require that a plaintiff prove the existence of a design defect through the negligence-like risk-utility test to hold the manufacturer liable. ${ }^{370}$

A party whose conduct is both tortious and a cause of the accident involving autonomous vehicles might be held liable in either of two ways depending on how the technology of autonomous vehicles develops. In an accident with autonomous vehicles employing vehicle-tovehicle communication, the electronic "paper trail" following an accident might reveal whether it was one of the autonomous vehicles, its driver, or the infrastructure that malfunctioned. ${ }^{371}$ In the absence of such devices, even if the plaintiff cannot prove which party(ies) engaged in tortious conduct contributing to the accident, some courts might find all parties jointly and severally liable under the doctrine of alternative liability. ${ }^{372}$

As noted previously, ${ }^{373}$ an important consequence of the replacement of driver-operated vehicles with autonomous vehicles is likely to be a shift in legal liability for the bulk of accident

\footnotetext{
368 See supra note 359 and accompanying text.

${ }^{369}$ See Michael D. Scott, Tort Liability for Vendors of Insecure Software: Has the Time Finally Come, 67 MD. L. REV. 425, 469 (2008) (reporting that "[t]o date, there are no reported decisions ... holding a software vendor liable under a strict liability theory.").

${ }^{370}$ Even proving that an autonomous vehicle is defective would be difficult. David Vladeck suggests that "[ $\left.\mathrm{t}\right] \mathrm{he}$ only feasible approach ... would be to infer a defect of some kind on the theory that the accident itself is proof of defect, ... which is simply a restatement of res ipsa loquitor." Vladeck, supra note 343, at 128.

${ }^{371}$ One commentator has suggested that manufacturers could protect themselves from unwarranted liability if each autonomous vehicle is equipped with an "Event Data Recorder ... analogous to the Flight Data Recorders ... colloquially known as a 'black box,' found on airplanes.”). Bose, supra note 367, at 1326. Insurance companies already offer the prospect of lower insurance premiums for those drivers that agree to incorporate monitoring devices into their vehicles that track driving performance. See Ron Lieber, Lower Your Car Insurance Bill, at the Price of Some Privacy, N.Y. TIMES (Aug. 15, 2014), https://www.nytimes.com/2014/08/16/your-money/autoinsurance/tracking-gadgets-could-lower-your-car-insurance-at-the-price-of-some-privacy.html. 372 See, e.g., Menne v. Celotex Corp., 861 F.2d 1453, 1474 (10th Cir. 1988) (shifting burden to defendant manufacturers to prove absence of factual causation); Abel v. Eli Lilly \& Co., 343 N.W. 2d 164, 176-77 (Mich. 1984) (shifting the burden to defendant manufacturers under the alternative liability theory).

${ }^{373}$ See supra notes 360-361, and accompanying text.
} 
costs from drivers to vehicle-manufacturers. Obviously, this will have significant implications for liability insurance. Automobile insurance premiums will plummet because legal liability for most of the accident costs now covered by liability and collision insurance will be transferred to vehicle manufacturers. ${ }^{374}$ Once a manufacturer has sold a vehicle, however, there probably is no practical way for the manufacturer to be reimbursed for its ongoing, annual insurance premiums covering the expected liability. Hence, the distribution of autonomous vehicles from manufacturers to consumers probably will be altered in one or more of several ways. First, if the autonomous vehicle is sold to an individual driver, the upfront purchase price will include the present discounted value of the amounts the manufacturer expects to spend during the useful life of the autonomous vehicle on accident costs, through either insurance premiums or selfinsurance. ${ }^{375}$ Second, the manufacturer's liability for the costs of accidents involving autonomous vehicles makes it more likely that the vehicles will be leased, rather than sold, and that annual lease payments will include the manufacturer's expected liability costs. ${ }^{376}$ Third, today's norm of privately-owned automobiles may be replaced with a system in which ridesharing businesses such as Uber or Lyft own the vast majority of autonomous vehicles and provide transportation for private parties on an individual-ride basis. ${ }^{377}$ The recent proliferation of partnerships among ridesharing businesses, automobile manufacturers, and software corporations is no coincidence. ${ }^{378}$

Let us now apply the four factors considered in Part IV to accidents involving autonomous vehicles:

\footnotetext{
${ }^{374}$ See Crane et al., supra note 350, at 49, 256 (concluding that "[ $\left.\mathrm{t}\right]$ he most likely outcome is that premiums for driver liability coverage, as well as first-party health and lost-income coverage ... will decline"); KALRA ET AL., supra note 347, at 21 (anticipating lower insurance premiums for owners of autonomous vehicles).

375 See Smith, supra note 343, at 57 (finding that "[ $\mathrm{t}]$ he price of automated driving products and services will reflect the product liability exposure of that industry.").

${ }^{376} \mathrm{Id}$. at 62 (analyzing liability costs if autonomous vehicles are leased).

${ }^{377} I d$. at 65, 68 (outlining the advantages of a service-model for autonomous vehicles that would substitute for private ownership of vehicles).

378 See, e.g., KALRA ET AL., supra note 347, at 194 (reporting on General Motors' purchase of Cruise Automation for $\$ 1$ billion and its substantial investment in Lyft, a ridesharing company).
} 
(1) The frequency of accidents resulting from the proliferation of autonomous vehicles will be dramatically decreased from the current frequency of automobile accidents. ${ }^{379}$

(2) The severity of the remaining accidents likely will be greater than those resulting from current automobile accidents. ${ }^{380}$

However, the aggregate liability exposure (frequency times severity) will still be considerably less than under the current system. ${ }^{381}$

(3) The difficulty of proving liability will depend on whether autonomous vehicle manufacturers include event data recorders within the vehicles. ${ }^{382}$ If they do, the difficulty of proving liability may not be substantially greater than under the current automobile system, but proof of liability will still require technical expertise. If event data recorders are not included, proving liability, both causation and negligence, will be substantially more difficult than under the current system.

(4) The social utility of the proliferation of autonomous vehicles is great. ${ }^{383}$ Much of this increased social utility results from the dramatic decline in the frequency of accidents, but other social benefits will include the ability of children and disabled persons to travel in such vehicles without an able-bodied adult present, greater density of traffic (thus requiring fewer roads and travel lanes), and greater convenience.

The difficulties of proving that any particular party within the autonomous vehicle system, including the manufacturers of the vehicles, operators of the infrastructure, software engineers, or drivers of the vehicles, caused an accident and engaged in tortious conduct (e.g., the product was defective) suggest some form of collective liability for the purpose of compensating personal injury victims. ${ }^{384}$ Manufacturers of autonomous vehicles and those responsible for designing, building, and maintaining the infrastructure would be assessed to provide the compensation pool from which injured victims will be compensated. Witt notes that workers' compensation is really a system that dispenses with proof of factual causation as well as fault, ${ }^{385}$ and the same principle would apply here.

\footnotetext{
379 See supra notes 354-355, and accompanying text.

380 See supra note 356 and accompanying text

381 See supra note 357 and accompanying text.

${ }^{382}$ See supra note 371 and accompanying text.

383 See KALRA ET AL., supra note 347, at 5-6.

${ }^{384}$ See Vladeck, supra note 343, at 146 (proposing a strict liability, "court-compelled insurance regime").

385 See supra note 330.
} 
The principal distinction between a strict liability and a no-fault system is whether the liability system is administered by common law courts in which juries typically determine damages or no-fault administrative agencies where damages are limited and typically do not include compensation for noneconomic damages. As was the case during the nineteenth century, the expected high social utility of autonomous vehicles is relevant to the choice between a common-law strict liability approach and a no-fault compensation system. Society may legitimately decide that because of the extremely significant overall improvement in safety resulting from autonomous vehicles and other positive aspects of autonomous vehicles, ${ }^{386}$ the development of the autonomous-vehicle technology should be subsidized. The goal of using the liability system to subsidize a safer, beneficial transportation system suggests that the task of assessing the costs of accidents be withdrawn from common law courts and juries and transferred to administrative agencies. Additionally, this change may be justified because jurors' widespread skepticism about complex technologies and resentment toward corporations that promote such technologies might result in unwarranted findings of liability and excessive damages. ${ }^{387}$

There are contrary arguments that suggest that common law liability should apply to autonomous vehicle accidents. ${ }^{388}$ Some manufacturers of autonomous vehicles and the accompanying infrastructure may be less careful in the design and implementation of the autonomous vehicle system than others, and the limitations on damages present in no-fault compensation systems reduce the incentives to minimize losses. Proponents of no-fault liability

\footnotetext{
${ }^{386}$ See KALRA ET AL., supra note 347, at 5 (noting advantages of autonomous vehicles for members of the disabled and elderly communities).

${ }^{387}$ See Lance Ulanoff, How Trump Won an Election Helped by America's Anti-Tech Luddites, MASHABLE (Nov. 16, 2016), http://mashable.com/2016/11/16/trump-tech-vote/\#zwBX46T7Lmqi (observing "that tech and innovation weren't necessarily positive terms in the heartland. ... Technology wasn't the answer for these voters because it was, essentially, the villain").

${ }^{388}$ For example, Vladek argues in favor of a "strict liability" regime instead of a no-fault regime. See Vladeck, supra note 343, at 146-48. He wants the compensation scheme to be administered by common law courts and not administrative agencies, and he cites recent studies showing that automobile no-fault compensation systems have not reduced transaction costs as their proponents originally anticipated. See Vladeck, supra note 343, at 147 n.91.
} 
would rely on regulatory agencies and market pressures to provide the incentives to minimize accidents, but this has not always proven to be a safe assumption. ${ }^{389}$

To be effective, a no-fault liability system for autonomous vehicles would require congressional enactment. Common law courts could not adopt any system that limited the damages received by victims. Any attempt by a state legislature to enact a no-fault compensation system would not be effective in creating a subsidy to encourage the development of an autonomous-vehicle network. Manufacturers operate in a national marketplace and their vehicles travel across state borders, subjecting manufacturers to liability in states that have not enacted no-fault compensation systems. ${ }^{390}$ During the past half-century, a well-organized plaintiff's bar vigorously fought the adoption of no-fault compensation systems in virtually all contexts in which they were proposed. ${ }^{391}$ Lawsuits arising from automobile accidents are the bread-and-butter of the vast majority of plaintiffs' counsel, ${ }^{392}$ and thus it is unlikely that their opposition would be anything other than fierce.

\section{Conclusion}

\footnotetext{
389 See generally RenA STEInZOR \& Sidney SHAPIRO, THE PEOPlE’S AgENTS: SPECIAL InTERESTS, GOVERNMENT, AND THREATS TO HEALTH, SAFETY, AND THE ENVIRONMENT (2010) (explaining how regulatory failures have afflicted health, safety, and environmental programs government-wide due to budget shortfalls, outdated authorizing statutes, and lack of political support from the White House and Congress).

${ }^{390}$ A state that declines to enact a no-fault liability system with limited damages for accidents caused by autonomous vehicles, while other states do so in an effort to subsidize autonomous-vehicle technology, would prevent the other states from realizing the benefits of subsidization. See Maxwell L. Stearns, A Beautiful Mend: A Game Theoretical Analysis of the Dormant Commerce Clause Doctrine, 45 WM. \& MARY L. REV. 1, 78 (2003); cf. Kassel v. Consol. Freightways Corp., 450 U.S. 662, 671 (1981) (illustrating how one state's exercise of its police powers that differs from that of most other states interferes with interstate commerce and hence violates the Commerce Clause); Bibb v. Navajo Freight Lines, 359 U.S. 520, 528 (1959) (discussing how conflicting exercises of states' police powers create a "massive ... burden on interstate commerce").

391 See ThOMAS F. BURKE, LAWYERS, LAWSUITS, AND LEGAL RIGHTS: THE BATTLE OVER LITIGATION IN AMERICAN SOCIETY 103-41, 171-89 (2002) (describing the success of the California Trial Lawyers Association in blocking nofault legislation); Jeffrey O'Connell \& Robert H. Joost, Giving Motorists a Choice Between Fault and No-fault Insurance, 72 VA. L. REV. 61, 75 (1986) (describing opposition of trial lawyers to no-fault plans).

${ }^{392}$ Cf. Sarah Parikh \& Bryant Garth, Philip Corboy and the Construction of the Plaintiffs' Personal Injury Bar, 30 LAW \& SOC. INQUIRY 269, 271 n.1 (2005) (noting that “[t]he majority of Chicago plaintiffs' lawyers handle a high volume of smaller cases - mostly automobile accidents"); Charles Silver, Preliminary Thoughts on the Economics of Witness Preparation, 30 TEX. TECH L. REV. 1383, 1384 (1999) (describing automobile accidents as "the bread and butter of the typical plaintiff's attorney.").
} 
Legal historians and tort scholars have failed to pay sufficient attention to the primary role played by technological change in the law governing compensation for personal injuries. The first great transformation of American tort law, the adoption of the negligence regime, occurred during the mid-nineteenth century when courts for the first time faced numerous claims from victims of personal injuries caused by post-Industrial Revolution machinery, particularly railroads. ${ }^{393}$

The second major set of changes in American accident compensation law, which I regard as delayed aftershocks of the Industrial Revolution, began when most workplace injuries were removed from the common law tort system and handled within the separate workers' compensation system. ${ }^{394}$ Once again, the impacts of technology on the economy, here the development of the factory system and the proliferation of railroads and other industrial machinery, contributed to the change. ${ }^{395}$ Within decades, the proliferation of the automobile culture and the mass injuries it produced resulted in the formal enactment of workers'compensation-type no-fault systems in a minority of states. Moreover, in most states, the negligence regime remained nominally intact, but now functioned more like a no-fault system than the traditional negligence regime. ${ }^{396}$ Finally, during the 1960 s and 1970s, the mass consumer society appeared to result in another important change in American tort law, the adoption of strict products liability. ${ }^{397}$ Over the longer term, however, this change in the law turned out to be more apparent than real. ${ }^{398}$

From this history, in this Article I derive a descriptive model for analyzing and predicting what changes in accident compensation law will result from the adoption of new technologies. The model suggests that changes in tort law will follow from technology-caused changes in the

\footnotetext{
393 See supra notes 65-92, 126-147, 153-159, 190-202, and accompanying texts.

${ }^{394}$ See supra notes 218-230, and accompanying text.

395 See supra notes 213-217, and accompanying text.

${ }^{396}$ See supra notes 265-278, and accompanying text.

${ }^{397}$ See supra notes 288-295, and accompanying text.

${ }^{398}$ See supra notes 305-320, and accompanying text.
} 
following four variables: (1) the frequency of accident injuries resulting from the new technology, (2) the severity of injury resulting from the technological innovations, (3) the difficulty facing the claimant in proving the prerequisites of liability, and (4) the social utility of the new technology.

Society is now in the early phases of a technological revolution that will rival the Industrial Revolution in importance, one involving robots, artificial intelligence, and, most importantly, autonomous vehicles. ${ }^{399}$ During the nineteenth and twentieth centuries, postIndustrial-Revolution machines replaced the power and force previously supplied by human beings and horses. Now machines are replacing the decision-making previously supplied by humans. ${ }^{400}$

Application of the model's factors to autonomous vehicles suggests the adoption of either a no-fault system or a strict, collective liability standard within the common law that requires proof of neither fault nor individual causation as a requirement of liability. The choice between these two alternatives should be made on the basis of two factors: (1) the extent to which we trust administrative regulation to assure an adequate level of attention to safety consideration in the development of an autonomous vehicle system, and (2) the need to subsidize the development of the autonomous vehicle system that offers great positive social utility. Regardless of the choice, the next technology-inspired revolution in American tort law looms on the horizon.

\footnotetext{
${ }^{399}$ See supra notes 347-353, and accompanying text.

${ }^{400}$ See supra notes 342-343, and accompanying text.
} 